\title{
ADMINISTRAÇÃO SISTÊMICA DE ROSIGLITAZONA ESTIMULA A APOPTOSE DE OSTEÓCITOS E CEMENTÓCITOS, INTERFERINDO NO DESENVOLVIMENTO DE LESÕES PERIAPICAIS INDUZIDAS EM CAMUNDONGOS
}

Tese apresentada à Faculdade de Odontologia de Ribeirão Preto da Universidade de São Paulo, para obtenção do título de Doutor em Ciências.

Programa: Odontopediatria

Área de Concentração: Odontopediatria

Orientador: Profa. Dra. Raquel Assed Bezerra Segato Co-orientador: Prof. Dr. Gustavo Pompermaier Garlet 
AUTORIZO A REPRODUÇÃO E/OU DIVULGAÇÃO TOTAL OU PARCIAL DA PRESENTE OBRA, POR QUALQUER MEIO CONVENCIONAL OU ELETRÔNICO, DESDE QUE CITADA A FONTE.

Katharina Morant Holanda de Oliveira

\section{Ficha Catalográfica}

Oliveira, Katharina Morant Holanda

Administração sistêmica de Rosiglitazona estimula a apoptose de osteócitos e cementócitos, interferindo no desenvolvimento de lesões periapicais induzidas em camundongos. Ribeirão Preto, 2017.

95p. : il. ; $30 \mathrm{~cm}$

Tese de Doutorado apresentada à Faculdade de Odontologia de Ribeirão Preto/USP - Área de Concentração: Odontopediatria.

Orientador: Profa. Dra. Raquel Assed Bezerra Segato

1.Camundongos; 2.Rosiglitazona; 3.Osteócitos; 4.Cementócitos;

5.Apoptose; 6.Análise microscópica; 7. Lesão periapical;

8.Expressão gênica 
Katharina Morant Holanda de Oliveira

\title{
ADMINISTRAÇÃO SISTÊMICA DE ROSIGLITAZONA ESTIMULA A APOPTOSE DE OSTEÓCITOS E CEMENTÓCITOS, INTERFERINDO NO DESENVOLVIMENTO DE LESÕES PERIAPICAIS INDUZIDAS EM CAMUNDONGOS
}

\author{
Tese apresentada à Faculdade de Odontologia de Ribeirão Preto da \\ Universidade de São Paulo, para obtenção do título de Doutor em \\ Ciências. \\ Programa: Odontopediatria \\ Área de Concentração: Odontopediatria \\ Orientador: Profa. Dra. Raquel Assed Bezerra Segato \\ Co-orientador: Prof. Dr. Gustavo Pompermaier Garlet
}

Data da defesa:

\section{Banca Examinadora}

Prof. Dr.

Julgamento:

Assinatura:

Prof. Dr.

Julgamento:

Assinatura:

Prof. Dr.

Julgamento:

Assinatura:

Prof. Dr.

Julgamento:

Assinatura:

Prof. Dr.

Julgamento:

Assinatura: 



\title{
DADOS CURRICULARES \\ Katharina Morant Holanda de Oliveira
}

\author{
Nascimento 21 de fevereiro de $1988-$ Recife/PE \\ Filiação Jorge Luiz Cordeiro de Oliveira \\ Maria da Penha Morant Holanda de Oliveira \\ 2006-2010 \\ Curso de Graduação \\ Faculdade de Odontologia - UFPE \\ 2008-2009 Iniciação Científica - Bolsista CNPq \\ Universidade Federal de Pernambuco \\ 2009-2009 \\ Curso de Atualização em Periodontia \\ Sindicato dos Odontologistas do Estado de Pernambuco \\ 2010-2011 Aperfeiçoamento em Odontopediatria \\ Centro de Pós-Graduação em Odontologia \\ 2011-2012 Aperfeiçoamento em Atendimento Odontológico a \\ Pacientes Especiais. \\ Faculdade de Odontologia de Ribeirão Preto - FORP/USP \\ 2011-2013 Curso de Especialização em Odontopediatria \\ Associação Odontológica de Ribeirão Preto - Ribeirão Preto/SP \\ 2011-2013 Curso de Pós-Graduação (Mestrado) em Odontologia \\ Área de Concentração: Odontopediatria. Bolsista CAPES \\ Faculdade de Odontologia de Ribeirão Preto/USP \\ 2013-2017 Curso de Pós-Graduação (Doutorado) em Odontologia \\ Área de Concentração: Odontopediatria. Bolsista CAPES \\ Faculdade de Odontologia de Ribeirão Preto/USP
}





\begin{abstract}
ASSIM MMESMO
Muitas vezes as pessoas são egocêntricas, ilógicas e insensatas.

Perdoe-as assim mesmo.
\end{abstract}

Se você é gentil, as pessoas podem acusá-lo de egoísta, interesseiro.

Seja gentil, assim mesmo.

Se você é um vencedor, terá alguns falsos amigos e alguns inimigos verdadeiros.

Vença assim mesmo.

Se você é honesto e franco, as pessoas podem enganá-lo.

Seja honesto assim mesmo.

O que você levou anos para construir, alguém pode destruir de uma hora para outra.

Construa assim mesmo.

Se você tem Paz e é Feliz, as pessoas podem sentir inveja.

Seja Feliz assim mesmo.

Dê ao mundo o melhor de você, mas isso pode nunca ser o bastante.

Dê o melhor de você assim mesmo.

Veja que, no final das contas, é entre você e DEUS.

$\mathcal{N}$ unca foi entre você e as outras pessoas.

Madre Teresa de Calcutá

(Adaptado de: Os mandamentos Paradoxais, Kent Keith) 



\section{OFEREÇO ESSE TRABALHO}

Ofereço este trabalho a Deus, por todas as bênçãos e proteção tão vivas em mim. Senhor, muito obrigada pela vida, desafios e conquistas. 



\section{DEDICATÓRIA}

Dedico esse trabalho à minha avó Maria Tereza Morant de Holanda (in memoriam), que está sempre presente em minha vida, me guiando pelos melhores caminhos. Agradeço pelo amor e ensinamentos, que construíram uma família repleta de carinho, união e respeito. Voinha, você sempre será o meu exemplo de vida.

Aos meus pais Jorge Luiz Cordeiro de Oliveira e Maria da Penha Morant Holanda de Oliveira, os melhores pais desse e de qualquer mundo. Obrigada por toda a dedicação e apoio incondicional. Tenho muito orgulho de ser filha de vocês.

Às minhas irmãs Nathalia Morant Holanda de Oliveira e Dianna Morant Holanda de Oliveira. Vocês me completam e enchem minha vida de alegria. Sei que tenho em vocês companheiras pra qualquer diversão e desafio. Obrigada por sermos três e ao mesmo tempo uma só. Amo vocês.

Aos meus padrinhos Ricardo Morant de Holanda e Maria do Socorro Bonfim Moraes Morant de Holanda, meus tios Romildo Morant de Holanda e Keila Vasconcelos Holanda e primos. Obrigada por todo o carinho, apoio e incentivo. A nossa união é um presente de Deus.

À minha madrinha, Lucemar Cordeiro de Oliveira, por todo carinho e sempre me estimular no caminho da fé.

Ao meu namorado José Ricardo Vanderlei, por sempre me apoiar, sempre incentivar e concretizar meus sonhos! Obrigada por acreditar tanto no meu potencial e por ter trazido paz e alegria à minha vida. Sei que juntos vamos mais longe. Amo você!

À família de Ribeirão Preto e Ipuã! Tantas pessoas que me confortaram em momentos difíceis e que sempre me ajudaram a superar a distância de casa. Muito obrigada por me acolherem com tanto carinho!

A todos os meus familiares... tios, tias, primos, cunfados, avós (in memoriam). Muito obrigada por existirem e fazerem parte da minha vida. Agradeço a Deus pela minha família!

Às crianças, por sempre me encantarem e representarem o motivo maior da minha dedicação.

Devo essa conquista a todos vocês

Obrigada por tudo! 



\section{AGRADECIMENTOS ESPECIAIS}

\section{Às queridas amigas em Ribeirão Preto}

Janine Montenegro, Mariana Alencar Nemezio, Priscilla Coutinho Romualdo e Rachel Fernanda Matos.

Por todos os momentos bons e ruins, que fazem parte de qualquer casa e convivência! Muito obrigada por todas as risadas, carinho e companfia! Espero que a distância nunca nos afaste.

\section{Aos queridos amigos em Ipuã}

$\mathcal{A}$ todos da casa da Tia Leta, por sempre me fazerem sentir como integrante da família e por trazerem mais alegria à minha vida! Que a união e carinho só aumente!

$\mathcal{A}$ todos da casa da Tia Rô, que sempre me acolheram com tanta alegria, fazendo-me sentir em casa. Vocês são muito especiais. Muito obrigada por tudo!

\section{Aos queridos Mestres}

À Profa Dra. Raquel Assed Bezerra Segato, minha orientadora. Muito obrigada por sempre me incentivar tanto, por sempre confiar e acreditar em mim, mesmo quando eu duvido! Obrigada pelo 6om-humor, paciência, ensinamentos compartilhados, disponibilidade, compreensão e palavras de conforto. Sem seu apoio nada disso seria possivel! Muito obrigada, profa!

Ao Prof. Dr. Paulo Nelson Filho, meu exemplo de mestre, por todas as orientações e ensinamentos. Muito obrigada pela disponibilidade, paciência, apoio, incentivo e zelo. Espero um dia alcançar suas expectativas!

À Profa. Dra. Lea Assed Bezerra da Silva, pela oportunidade, desafios e a imensa contribuição na minha formação profissional. Obrigada pelos ensinamentos, disponibilidade, apoio e confiança.

À Profa Dra. Kranya Victoria Díaz Serrano, por todo o carinho, ensinamentos, conselhos, consolo e acolhimento! É muito 6om saber que posso contar com a senhora!

Às amigas de doutorado, Driely Barreiros de Oliveira, Carolina Maschietto Puccinelfi, Daniela Silva Barroso de Oliveira, Ana Caroline Fumes, Daniele Lucca Longo, Fernanda Regina Ribeiro Santos, pelo companheirismo, 6om-humor, apoio e incentivo mútuos, momentos de descontração e estresse compartilhado durante o Doutorado! Cada uma do seu jeito tem uma participação especial na minha vida. Com vocês a jornada ficou mais leve! Espero que a distância nunca nos afaste. 



\section{AgRADECIMENTOS}

À Universidade de São Paulo, na pessoa do atual reitor, Prof. Dr. Marco Antonio Zago, e do vice-reitor, Prof. Dr. Vahan Agopyan.

À Faculdade de Odontologia de Ribeirão Preto da Universidade de São Paulo, na pessoa da atual diretora, Profa. Dra. Léa Assed Bezerra da Silva, e do vice-diretor, Prof. Dr. Arthur Belém Novaes Júnior.

À Coordenação do Curso de Pós-Graduação em Odontopediatria da Faculdade de Odontologia de Ribeirão Preto da Universidade de São Paulo, na pessoa da coordenadora, Profa. Dra. Raquel Assed Bezerra da Silva e da vice-coordenadora Profa. Dra. Lea Assed Bezerra da Silva.

À CAPES (Coordenação de Aperfeiçoamento de Pessoal de Nível Superior), pela bolsa concedida.

Aos professores da disciplina de Odontopediatria da Faculdade de Odontologia de Ribeirão Preto da Universidade de São Paulo:

Profa. Dra. Sada Assed, por representar uma eterna fonte de inspiração na Odontopediatria.

Profa. Dra. Aldevina Campos de Freitas, exemplo de dedicação à profissão, pela ternura e ensinamentos.

Profa. Dra. Alexandra Mussolino de Queiroz, pela simpatia, palavras de elogio e incentivo.

Profa. Dra. Andiara de Rossi, pelos ensinamentos, apoio e contribuições científicas, sempre enriquecedoras.

Profa. Dra. Cristina Borsatto, pela convivência sempre tão agradável, simpatia e ensinamentos transmitidos.

Profa. Dra. Erika Calvano Küchler, por ter me ensinado que consigo ser ainda mais prática do que eu pensava ser, por todos os ensinamentos, risadas, confiança e incentivo.

Prof Fabricio Kitazono de Carvalho, por todos os ensinamentos, estímulo e disponibilidade.

Profa. Dra. Maria da Conceição Pereira Saraiva, por todos os ensinamentos transmitidos.

A todos os professores convidados que tive a oportunidade de confecer durante o curso de Doutorado, pelos confecimentos transmitidos e por me inspirarem no caminho acadêmico.

Ao Prof. Dr. Gustavo Pompermaier Garlet, meu co-orientador neste trabalho, por todos os ensinamentos e disponibilidade, sempre muito solícito e pronto para solucionar qualquer dúvida.

Ao Prof. Dr. Marcio Matheus Beloti, por todas as sugestões tão pertinentes e sempre disposto a ajudar.

Ao Prof. Dr. Al6erto Consolaro, pelo 6om-humor, por todos os ensinamentos e por ser uma fonte de inspiração como docente. 
Aos professores da disciplina de Ortodontia da Faculdade de Odontologia de Ribeirão Preto da Universidade de São Paulo: Prof. Dr. Fábio Lourenço Romano, Prof. Dr. José Tarcísio Lima Ferreira, Profa. Dra. Mírian Aiko Nakane Matsumoto, Profa. Dra. Maria Bernadete Sasso Stuani, pela convivência agradável no mesmo departamento, pelas orientações e ensinamentos transmitidos.

Aos Funcionários da Faculdade de Odontologia de Ribeirão Preto

Marília Pacífico Lucisano, pela amizade, carinho e incentivo. Obrigada pela torcida sempre, Ma! Espero que a distância nunca nos afaste.

Nilza Letícia Magalhães, pelo 6om-humor, carinho, paciência e toda a ajuda técnica na realização deste trabalho! Foi muito bom poder contar com você, sempre! Você é uma pessoa abençoada!

Francisco Wanderlei Garcia de Paula e Silva e Carolina Paes Torres Mantovani, pela convivência agradável, tantos ensinamentos transmitidos, auxílio nas atividades de clínica e laboratoriais.

Marco Antônio dos Santos e Fátima Aparecida Jacinto Daniel por toda a ajuda nas atividades laboratoriais, apoio, disponibilidade, 6om-humor e convivência tão agradável.

Micheli Cristina Leite Rovanholo, Matheus Morelli Zanela e Filomena Leli Placciti, pela disponibilidade e atenção, conversas e convivência agrađável e pela prontidão em ajudar!

À secretária do Programa de Pós-Graduação Mary Possani Carmessano, por toda a ajuda durante o curso de Doutorado e parceria em todas as Comissões das quais fiz parte! Foi um prazer trabalhar com você!

À secretária do curso de Especialização de Ortodontia Rosemary Alves de Sá pela convivência tão agradável e pela formatação deste trabalho.

Aos funcionários da Clínica 1: José Aparecido JNeves do Nascimento, Vera do Nascimento Scandelai e Karina Dadalt Quaglio, pela convivência agradável e pelo apoio nas atividades de clínica junto à graduação.

Aos funcionários do Biotério da Faculdade de Odontologia de Ribeirão Preto da Universidade de São Paulo, Antônio Sérgio Aparecido Mesca, Aline Aparecida Ferraresi Tiballi, Antônio Massaro e Raphael Martini Vicente, pela paciência, disposição em ajudar e cuidado com os animais.

Aos colegas da Pós-Graduação em Odontopediatria da Faculdade de Odontologia de Ribeirão Preto da Universidade de São Paulo, Ana Zilda Sazar Bérgamo, Ana Maria Guerra Costa, Ana Paula Dias Moreno, Arthur Cunha da Silva, Danielly Cunha Araújo Ferreira, Denise de Souza Matos, Elaine Machado Pingueiro Okada, Fernanda Vicioni Marques, Francine Lorencetti da Silva, Gabriela Cristina Sautin, Guido Artemio Marañón Vasquez, José Guilherme Neves, Juliana Arid, Karina Grecca Pieroni, Karla Orfelina Carpio Horta dos Reis, Késsia Suênia Fidélis de Mesquita, Larissa Nogueira Soares Ribeiro, Lidia Regina da Costa Hidalgo, Mariana Trevizan, Mariana Vmekita Shirozaki, Marina Moscardini Vilela, Marília Rodrigues Moreira, Paula Regina Ávila Silvano, Raquel Fernanda Morelli, Silvana Polizeli, Silvia Elena Paredes, Stephanie Diaz Huaman, Thaís Xavier, Thaise Mayumi Taira, Talitha de Siqueira Mellara, Mariele Andrade e Patrícia Monteiro, pelo incrivel "intercâmbio cultural", por todo o apoio, troca de experiências e pela convivência sempre agradável. 
Às amigas da graduação, Fernanda de Albuquerque Almeida, Luciana Silva Regueira, Juliana Cameiro Leão, Priscylla Gonf̧alves Correia e Samantha Cardoso de Andrade, por terem dividido comigo uma das melhores experiências da minha jornada profissional: a formação em Odontologia. Obrigada pela amizade, risadas, apoio e carinho, mesmo à distância, e pela certeza de que sempre poderei contar com vocês!

Às amigas de infância, Gisele Cruz Camboim, Nathatia da Fonte Nogueira, Maria Jufiana Godoy, Camila Guedes Cabral de Amuda, Rebeca Mattos Queiroz, Thais Torres Rodrigues, Ana Cecíía Araújo, por me darem a certeza de que algumas coisas nunca mudam, e que nem o tempo nem a distância separam amizades verdadeiras. Obrigada pela união até hoje, por fazerem parte da minha alegria e serem minha terapia nos momentos dificeis.

A todos os familiares e amigos que sempre estiveram ao meu lado. 

Oliveira, KMH. ADMINISTRAÇÃO SISTÊMICA DE ROSIGLITAZONA ESTIMULA A APOPTOSE DE OSTEÓCITOS E CEMENTÓCITOS, INTERFERINDO NO DESENVOLVIMENTO DE LESÕES PERIAPICAIS INDUZIDAS EM CAMUNDONGOS. Ribeirão Preto, 2017 95p. [Tese Doutorado]. Ribeirão Preto: Faculdade de Odontologia de Ribeirão Preto da Universidade de São Paulo; 2017.

\section{RESUMO}

O tecido ósseo é um tipo especializado de tecido conjuntivo que desempenha funções essenciais para a sobrevivência do indivíduo, sendo composto predominantemente por osteócitos. Dentre os tecidos mineralizados do corpo, o cemento é um dos menos estudados e compreendidos. A apoptose em células do tecido ósseo têm sido relatada após o uso de Tiazolidinedionas (TZD), uma classe de medicamentos utilizada no tratamento do diabetes melitus tipo 2, representadas pela Rosiglitazona. Assim, os objetivos desse estudo foram: avaliar, in vivo, um protocolo de administração sistêmica da Rosiglitazona em camundongos a fim de estimular a apoptose de osteócitos em maxilares; o efeito da apoptose de osteócitos induzida por Rosiglitazona na formação e progressão de lesões periapicais em camundongos nos períodos experimentais de 7, 21 e 42 dias; e demonstrar a ocorrência de apoptose em cementócitos de camundongos os quais receberam ou não a Rosiglitazona. Foram utilizados camundongos wild type (C57BL/6) com 4 a 5 semanas de idade. No primeiro estudo, a etapa 1 foi realizada para definição de protocolo de administração sistêmica da Rosiglitazona para indução de apoptose em maxilares de camundongos. Os animais $(n=24)$ receberam a Rosiglitazona via oral por 1,2 ou 3 semanas (gavagem, dose de $10 \mathrm{mg} / \mathrm{kg}$ ) ou não (PBS+10\%DMSO). Foram utilizadas as técnicas de TUNEL e DAPI para quantificação de células apoptóticas. Posteriormente, na etapa 2, lesões periapicais foram induzidas nos primeiros molares inferiores de camundongos wild type (C57BL/6) $(n=60)$ após a administração ou não da Rosiglitasona. A câmara pulpar dos dentes foi exposta à microbiota da cavidade bucal pelos períodos de 7, 21 e 42 dias e os grupos foram divididos da seguinte forma: G1) veículo + lesão 7 dias; G2) veículo + lesão 21 dias; G3) veículo + lesão 42 dias; G4) TZD + lesão 7 dias; G5) TZD + lesão 21 dias; G6) TZD + lesão 42 dias. Foram realizadas avaliações em microscopia convencional para análise descritiva das lesões periapicais; microscopia de fluorescência para mensuração das lesões periapicais; histoenzimologia para a atividade da fosfatase ácida resistente ao tartarato (TRAP) e marcação de osteoclastos; absortometria radiológica de dupla energia (DXA) para avaliação da densidade mineral óssea (DMO) em osso longo e análise da expressão gênica de marcadores de osteócitos (Sost, Hyou1 e Dmp1). No segundo estudo, foram utilizadas as técnicas de TUNEL e DAPI para quantificação de cementócitos apoptóticos em dentes de 
camundongos wild type $(\mathrm{n}=12)$ que receberam ou não a Rosiglitazona. Na etapa 1 do primeiro estudo, pôde-se observar que a administração sistêmica da Rosiglitazona por 2 semanas promoveu a apoptose de osteócitos de forma mais expressiva quando comparada ao período de 1 semana, porém sem diferença significativa com o período de 3 semanas $(p>0,05)$. Já na etapa 2, nos grupos os quais receberam a Rosiglitazona, pôde-se observar uma tendência a lesões periapicais maiores, porém sem diferença estatisticamente significante em comparação com animais que não receberam esse medicamento ( $p>0,05)$, além de promover, aos 21 dias de progressão da lesão periapical, maior número de osteoclastos e maior expressão dos genes Sost e Hyou1, sem diferença estatisticamente significante para a expressão do gene Dmp1, bem como na DMO dos fêmures. Adicionalmente, no segundo estudo, foi observado que, em camundongos que receberam a Rosiglitazona por 2 semanas, os cortes histológicos corados em TUNEL e DAPI demonstraram maior razão de cementócitos apoptóticos/cementócitos totais comparado ao grupo controle. Após as metodologias empregadas e os parâmetros analisados, pôde-se concluir que o uso sistêmico da Rosiglitazona estimulou a apoptose de osteócitos e cementócitos interferindo na formação e progressão de lesões periapicais em camundongos.

Palavras-chave: camundongos, Rosiglitazona, osteócitos, cementócitos, apoptose, análise microscópica, lesão periapical, expressão gênica. 
Oliveira, KMH. SYSTEMIC ADMINISTRATION OF ROSIGLITAZONE STIMULATES APOPTOSIS OF OSTEOCYTES AND CEMENTOCYTES, INTERFERING IN THE DEVELOPMENT OF INDUCED PERIAPICAL LESIONS IN MICE. Ribeirão Preto, 2017. 95p. [Thesis] - School of Dentistry of Ribeirão Preto, University of São Paulo.

\begin{abstract}
The bone tissue is a specialized type of connective tissue that provides essential functions for the survival of the individual, composed predominantly of osteocytes. Among the mineralized tissues in the body, the cementum is one of the most poorly studied and understood. Apoptosis in the bone tissue have been reported after the use of Thiazolidinediones (TZD), a class of drugs used in the treatment of diabetes mellitus type 2 , represented by Rosiglitazone. Thus, the aims of this study were: evaluate, in vivo, a protocol for systemic administration of Rosiglitazone in mice in order to stimulate the apoptosis of osteocytes in jaws; the effect of apoptosis of osteocytes induced by Rosiglitazone in the formation and progression of periapical lesions in mice in the experimental periods of 7, 21 and 42 days; and demonstrate the occurrence of apoptosis in cementocytes of mice which received or not the Rosiglitazone. We used mice wild type (C57BL/6) with 4 to 5 weeks of age. In the first study, the phase 1 was performed for the protocol definition of systemic administration of Rosiglitazone for induction of apoptosis in mice jaws. The animals $(n=24)$ received the Rosiglitazone orally for 1,2 or 3 weeks (gavage, dose of $10 \mathrm{mg} / \mathrm{kg}$ ) or not (PBS+10\%DMSO). We used the techniques of TUNEL and DAPI for quantification of apoptotic cells. Subsequently, in phase 2, periapical lesions were induced in the first lower molars of wild type (C57BL/6) mice $(n=60)$ after the administration or not of Rosiglitasone. The pulp chamber was exposed to the oral microbiota during 7, 21 and 42 days, and the groups were divided as follows: G1) vehicle + periapical lesions 7 days; G2) vehicle + periapical lesions 21 days; (G3) vehicle + periapical lesions 42 days; (G4) TZD + periapical lesions 7 days; G5) TZD + periapical lesions 21 days; (G6) TZD + periapical lesions 42 days. Evaluations were conducted in conventional microscopy for descriptive analysis of periapical lesions; fluorescence microscopy for measurement of periapical lesions; histoenzimology to the activity of acid phosphatase resistant tartrate (TRAP) for osteoclasts measurement; dualenergy $x$-ray absorptiometry (DXA) for evaluation of bone mineral density (BMD) in long bone and analysis of gene expression of osteocytes markers (Sost, Hyou1 and Dmp1). In the second study, TUNEL and DAPI techniques were used for the quantification of apoptotic cementocytes in wild type $(n=12)$ mice that received Rosiglitazone or not. In the phase 1 of the first study it was observed that the systemic administration of Rosiglitazone for 2 weeks showed the apoptosis of osteocytes in a more expressive manner when compared to
\end{abstract}


the period of 1 week with no significant difference with the period of 3 weeks $(p>0,05)$. On phase 2, in the groups which received the Rosiglitazone, it was observed a tendency of larger periapical lesions, but without statistically significant difference compared with animals that did not receive this drug ( $p>0,05)$, besides promoting, at 21 days of periapical lesion progression, greater number of osteoclasts and greater expression of genes Sostand Hyou1, and absence of statistically significant differences in the expression of the gene Dmp1 nor in the BMD of the femurs. In addition, in the second study, it was observed that, in mice that received the Rosiglitazone for 2 weeks, sections stained by TUNEL and DAPI showed significantly higher ratio of apoptotic cementocytes/total cementocytes compared to control group. After the methodologies used and the parameters analyzed, it can be concluded that the systemic use of Rosiglitazone stimulated the apoptosis of osteocytes and cementocytes interfering in the formation and progression of periapical lesions in mice.

Keywords: mice, rosiglitazone, osteocytes, cementocytes, apoptosis, microscopic analysis, periapical lesion, gene expression. 


\section{SUMÁRIO}

INTRODUÇÃO.................................................................................................

Capítulo 1.

39

CAPítulo 2...

65

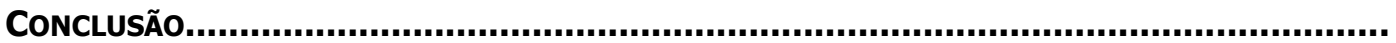

75

REFERÊNCIAS.

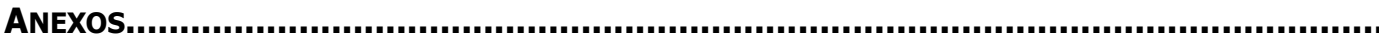



Introdução 



\section{O TECIDO ÓSSEO}

O tecido ósseo é um tipo especializado de tecido conjuntivo, rígido e dinâmico, que desempenha funções essenciais para a sobrevivência do indivíduo como suporte mecânico, proteção da medula óssea e sítio para a hematopoese, além de reservatório de cálcio, fosfato e outros íons (Weatherholt et al., 2012). Apresenta como particularidade uma constante remodelação, processo essencial para a manutenção da sua integridade e que depende do equilíbrio entre a reabsorção e a deposição óssea (Tate et al., 2004; Kular et al., 2012).

Esse tecido é composto por células, matriz rica em colágeno e outras glicoproteínas. O componente celular do tecido ósseo é compreendido pelos osteoblastos, células de superfície ou de revestimento (lining cells), osteoclastos e osteócitos (Robinson, 1979). Dentre esses tipos celulares, os osteócitos representam mais de $95 \%$ das células presentes e aumentam de número de acordo com a idade e o tamanho do osso (Tate et al., 2004; Bonewald, 2007; Rochefort et al., 2010; Dallas et al., 2013), enquanto que os osteoblastos correspondem a menos de $5 \%$ e os osteoclastos a menos que $1 \%$.

Para que o processo de constante remodelação óssea ocorra, destaca-se o sistema RANK/RANKL/OPG (Kawashima et al., 2007; Menezes et al., 2008; Wright et al., 2009; Garlet et al., 2010; Silva et al., 2012). Esse sistema é composto por três proteínas chaves: RANK (receptor ativador do fator nuclear kappa B), seu ligante RANKL (ligante do receptor ativador do fator nuclear kappa B) e seu receptor, a OPG (Osteoprotegerina). O RANK é um receptor transmembrana expresso em pré-osteoclastos, macrófagos e osteoclastos maduros. $\mathrm{O}$ RANKL é expresso por diversos tipos celulares incluindo osteoblastos, osteócitos, células da medula óssea, linfócitos T e B, fibroblastos e osteoclastos (Bonewald, 2011; O’Brien et al., 2013). Ele é responsável pela indução da reabsorção óssea por meio da estimulação da diferenciação e função de osteoclastos. A OPG regula o processo de reabsorção óssea com papel antagonista ao RANKL, evitando a ligação RANKL/RANK (Yasuda et al., 1998). Nesse contexto, é importante ressaltar que os osteócitos são os principais responsáveis pela expressão de RANKL e, por isso, apresentam grande influência na osteoclastogênese (Kular et al., 2012; O'Brien et al, 2013).

\section{OS OSTEÓCITOS}

Células mesenquimais da medula óssea dão origem aos osteócitos após diferenciação da linhagem de osteoblastos. Sabe-se que apenas 10 a $20 \%$ da diferenciação de osteoblastos, aproximadamente, resultam em osteócitos (Schaffler e Kennedy, 2012). Estas células se mantêm viáveis por décadas, enquanto os osteoblastos sobrevivem por semanas e 
os osteoclastos, por dias (Franz-Odendaal et al., 2006; Rochefort et al., 2010; Atkins e Findlay, 2012; Neve et al., 2012).

Os osteócitos são células mecano-sensitivas alojadas no interior da matriz óssea mineralizada e que possuem longos processos dendríticos, os quais atravessam a matriz óssea formando canalículos que conectam essas células entre si, com a corrente sanguínea e com células da superfície e da medula óssea (Tate et al., 2004; Bonewald, 2007; 2011), constituindo uma rede de comunicação altamente especializada (Mulcahy et al., 2011; Stern et al., 2012; Atkins e Findlay, 2012; Schaffler e Kennedy, 2012; Dallas et al., 2013). Os osteócitos e os seus processos dendríticos são permeados por um fluido intersticial (Bivi et al., 2012b). Esse sistema criado pelos osteócitos proporciona a transferência de sinais endógenos e exógenos por mecanismos mecânicos, elétricos e químicos.

Essas células, de sensibilidade superior aos osteoblastos, são capazes de responder à estimulação mecânica, em particular às forças de tensão (Klein-Nulend et al., 2002), promovendo a liberação de diversas moléculas, incluindo fatores de crescimento do tipo insulina, osteocalcina, esclerostina, c-fos, prostanóides e óxido nítrico (Uzbekov et al., 2012; Dallas et al., 2013).

Os osteócitos transmitem estímulos não apenas por meio da difusão de moléculas solúveis, mas também por contato celular direto realizado pelas junções tipo "gap" (Neve et al., 2012). Os sinais biomecânicos enviados pelos osteócitos regulam as atividades dos osteoblastos e osteoclastos, proporcionando um mecanismo que coordena a reabsorção e a aposição óssea, de acordo com as necessidades do tecido ósseo (Stern et al., 2012).

As junções do tipo "gap", localizadas nas extremidades dos prolongamentos dendríticos, desempenham importante papel na comunicação "célula-célula" de osteócitos adjacentes e de osteócitos com as células da superfície óssea (Loiselle et al., 2013). Essas junções são formadas por proteínas denominadas conexinas, com destaque para a conexina 43 (Cx-43), a qual é essencial para a manutenção da estrutura óssea e da viabilidade de osteócitos (Xu et al., 2015). Além disso, hemicanais encontrados em abundância na superfície dos osteócitos participam da comunicação extracelular por meio da liberação de moléculas envolvidas na remodelação óssea como a prostaglandina E2 (Cherian et al., 2005). Estes canais exibem uma baixa seletividade e permitem a passagem de pequenas moléculas ( $\leq 1 \mathrm{kDa}$ ) (Goodenough et al., 1996).

Diversas evidências destacam que os osteócitos não representam apenas o destino final dos osteoblastos. Por muitos anos, os osteócitos foram considerados células quiescentes, ou até mesmo "inativas", com limitado interesse fisiológico e patológico, devido à dificuldade do estudo destas células, as quais se encontram no interior da matriz óssea 
mineralizada (Rochefort et al., 2010; Neve et al., 2012), sendo mais comumente caracterizadas por sua morfologia e localização do que por sua função (Dallas et al., 2013). Atualmente, sabe-se que além de desempenharem função mecano-sensorial, eles são os principais reguladores da remodelação óssea, por meio da produção de fatores solúveis que atingem a medula óssea e influenciam na diferenciação e comportamento de osteoblastos e osteoclastos (Xiong et al., 2011; Bellido, 2014).

Além disso, a morte de osteócitos é acompanhada por grandes aumentos da expressão de RANKL no tecido ósseo, o qual desempenha um papel fundamental no aumento da reabsorção óssea (Tatsumi et al., 2007; O'Brien et al., 2013; Plotink, 2014), independentemente de o agente causal ser a atividade fagocítica de osteoclastos e/ou apoptose ou morte celular programada. A apoptose local pode ter um papel chave na regulação da reabsorção óssea já que, quando submetidos a este processo, os osteócitos transmitem sinais através dos canalículos para a superfície do endósteo para recrutar, ativar ou modular a atividade dos osteoclastos (Al-Dujaili et al., 2011; Atkins e Findlay, 2012; Kular et al., 2012; Schaffler e Kennedy, 2012). Kogianni et al. (2008) demonstraram que corpos apoptóticos derivados da linhagem celular MLO-Y4 (osteócitos-like) são capazes de estimular a diferenciação de osteoclastos, independentemente da presença de RANKL, suportando a hipótese que a presença de osteócitos apoptóticos pode alterar o meio ambiente ósseo em termos de localização de atividade reabsortiva.

\section{RECENTES DESCOBERTAS RELACIONADAS AOS OSTEÓCITOS}

Até a década passada, observava-se na literatura escassez de conhecimento a respeito dos osteócitos e suas importantes funções (Dallas et al., 2013). Entretanto, o uso de tecnologias transgênicas combinadas com biologia molecular e celular têm atribuído atualmente a estas células um papel chave na resposta a vários estímulos que regulam a formação e a remodelação óssea, bem como a regulação endócrina do metabolismo ósseo (Neve et al., 2012; Dallas et al., 2013). Assim, o osso foi reconhecido como um órgão endócrino por secretar dois hormônios na circulação: a osteocalcina e o fator de crescimento de fibroblastos 23 (FGF-23). Esse eixo endócrino, que envolve a liberação do FGF-23 a partir de osteoblastos e os osteócitos, regula a homeostase de fosfato sistêmico e o metabolismo da vitamina D (Quarles, 2003). A FGF-23 tem como alvo principal o rim, modulando a concentração de fosfato, uma função essencial para o desenvolvimento normal do esqueleto e para a preservação da integridade óssea (Quarles, 2003).

Avanços recentes nos estudos da biologia celular no tecido ósseo permitiram também a identificação de diferentes marcadores de membrana, nucleares e citoplasmáticos. Dentre esses marcadores, destacam-se algumas moléculas específicas como fatores de transcrição e 
outras proteínas relacionadas com o perfil de expressão nos osteócitos, a fim de se determinar o seu estágio de maturação (transição de osteócitos jovens até osteócitos maduros) (Narayanan et al., 2003; Franz-Odendaal et al., 2006; Dallas e Bonewald, 2010; Montesi et al., 2016).

\section{MARCADORES DE OSTEÓCITOS}

O estudo de diferentes marcadores celulares presentes na membrana, núcleo ou citoplasma permite determinar o estágio de maturação celular dos osteócitos e o conhecimento de suas funções. A diferenciação de osteoblatos em osteócitos é acompanhada de uma redução progressiva de alguns marcadores ósseos como fosfatase alcalina, sialoproteína óssea, osteocalcina, cólageno tipo I e RUNX2 (Runt related transcription fator 2); da manutenção de alguns marcadores como osteopontina, $\beta 3$ integrina e E11/gp38; além do aumento na expressão de outros, como a proteína reguladora de oxigênio 150 (ORP150), proteína da matriz dentinária 1 (DMP1) e fosfoglicoproteína da matriz extracelular (MEPE) (Franz-Odendaal et al., 2006). Além disso, outros marcadores dos osteócitos recentemente identificados podem ser destacados, como o gene fosfato-regulador com homologia a endopeptidase no cromossomo X (PHEX), o fator de crescimento de fibroblastos 23 (FGF-23) e a esclerostina (Kamiya e Takagi 2001; Toyosawa et al., 2001; Gu et al., 2006; Lorenz-Depiereux et al., 2006; Harris et al., 2007) Figura 1.

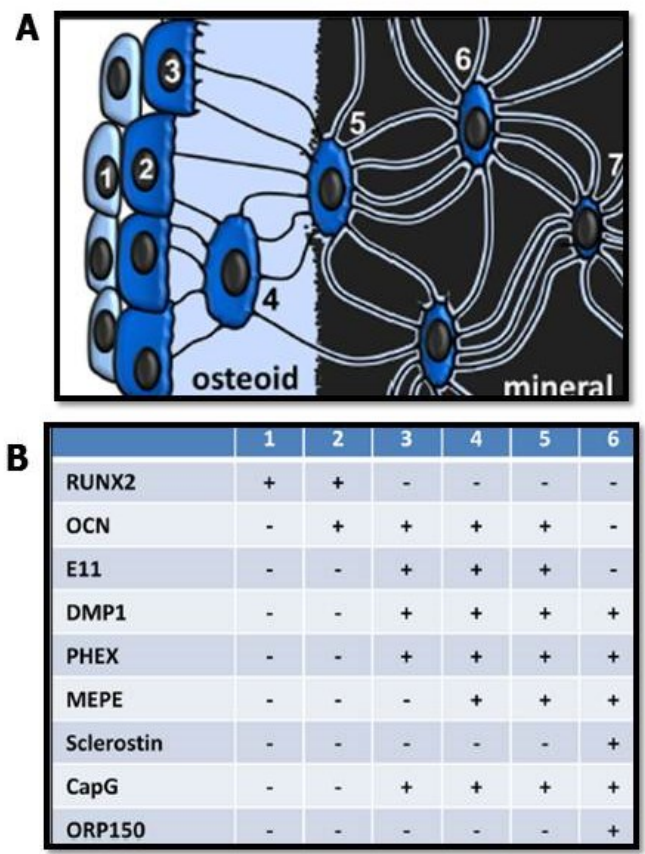

Figura 1. A) Diagrama esquemático com as fases de diferenciação de osteoblastos maduros para osteócitos. 1) préosteoblastos; 2) osteoblastos; 3) incorporação de osteoblastos na matriz não-mineralizada; 4) osteócito "osteóide"; 5) osteócito em mineralização; 6 e 7) osteócitos maduros. B) Quadro que ilustra a expressão temporal relativa de vários marcadores osteogênicos durante a transição de osteoblastos para osteócitos. Adaptado de Dallas et al., 2013. 
Dentre os marcadores de osteócitos, pode-se destacar a DMP-1. Ela é uma fosfoglicoproteína membro da família SIBLING (small integrin binding ligand) de proteínas da matriz não colágena em tecidos mineralizados geneticamente relacionadas, e foi identificada pela primeira vez no órgão dentário em odontoblastos (Butler et al., 1997). Devido a sua natureza altamente ácida, a DMP1 pode se ligar ao cálcio e assim regular a mineralização da matriz óssea (George et al., 1993).

A DMP1 pode regular a diferenciação de odontoblastos e osteoblastos como um ligante de integrina extracelular ou como um fator de transcrição. Estudos demonstraram que o seu papel regulatório se inicia com a ligação da DMP1 com receptores de integrina seguida da ativação da via de sinalização MAPkinase (Kulkarni et al., 2000; Jiang et al., 2010; Wu et al., 2011). Foi demonstrado, ainda, que a DMP1 foi identificada, in vitro, no núcleo de osteócitos (Huang et al., 2008; Maciejewska et al., 2009) e que apresenta um sinal de localização nuclear (NLS), que parece funcionar como um fator de transcrição (Narayanan et al., 2003).

Por outro lado, a DMP-1 secretada é uma proteína altamente fosforilada e liberada pelas células formadoras de tecido ósseo após o seu comprometimento em se tornar osteócitos (Narayanan et al., 2003; Eapen et al., 2010).

Camundongos deficientes para o gene da proteína DMP1 apresentaram maturação anormal de osteócitos e deficiência no desenvolvimento do seu sistema lacuno-canalicular (Feng et al., 2006), além de fenótipo de hipomineralização e níveis elevados de FGF-23, um regulador chave do fosfato e do metabolismo da vitamina $D$ como já mencionado (Neve et al., 2012).

Tendo em vista que a DMP1 é expressa predominantemente por osteócitos, enquanto que outras proteínas da matriz óssea (incluindo osteopontina, osteocalcina e sialoproteína óssea) são produzidas também por osteoblastos (Mark et al., 1988; Chen et al., 1992; Toyosawa et al., 2001), a proteína DMP1 circulatória poderia representar um biomarcador da atividade de osteócitos, assim como do processo de mineralização do tecido ósseo.

Assim, Sato et al. (2013) avaliaram o potencial dessa proteína como biomarcador do metabolismo ósseo, por meio da análise quantitativa dos níveis de DMP1 circulatório no sangue de ratos de diferentes idades. Os autores relataram que os níveis circulatórios de DMP1 podem representar um marcador de osteócitos imaturos e não altamente diferenciados.

Na Odontologia, com o objetivo de estabelecer novos marcadores para a identificação de células osteoprogenitoras no folículo dental e no ligamento periodontal para a regeneração dos tecidos, San Miguel e colaboradores (2010) utilizaram camundongos 
trangênicos para o gene DMP1 ligado a uma proteína verde fluorescente, expressa principalmente em pré-osteócitos, osteócitos e odontoblastos. Os autores observaram a expressão de DMP1 em odontoblastos e osteócitos, mesmo em estágios tardios de culturas de células do folículo dental e relacionadas com áreas de mineralização. Nestas áreas, foi observada intensa atividade de fosfatase alcalina, presença de nódulos de mineralização e um aumento na expressão de sialoproteína óssea, osteocalcina e DMP1. Estes resultados sugerem mais estudos, a fim de definir marcadores específicos de células maduras do periodonto e facilitar o isolamento, a purificação e a implantação destas células como uma forma para promover a reparação periodontal.

Além da DMP1, dentre os marcadores de osteócitos pode-se destacar a glicoproteína esclerostina. Codificada pelo gene Sost, ela está relacionada com a diferenciação de osteoblastos em osteócitos maduros através da regulação de PHEX e MEPE (Winkler et al., 2003; Atkins et al., 2011).

Ela é expressa especificamente em osteócitos e inibe a atividade de osteoblastos e a formação óssea por meio de uma ação antagônica na via de sinalização Wnt, se ligando aos co-receptores LRP5 e LRP6 (Schaffler e Kennedy, 2012). Estudos demonstraram que animais deficientes de esclerostina, simulando patologias conhecidas como a esclerosteose e a doença de van Buchem, exibiram aumento da formação óssea trabecular e cortical (Winkler et al., 2003; van Bezooijen et al., 2004; Bellido et al., 2005; Li et al., 2005; Poole et al., 2005; Semenov et al., 2005).

Sabe-se que a esclerostina a estimula a regulação de RANKL e inibe a regulação da expressão de OPG por osteócitos, aumentando a diferenciação e atividade de osteoclastos, conduzindo à reabsorção óssea. Recentemente, tem sido demonstrado que na ausência de carga mecânica, a expressão de RANKL é aumentada em osteócitos (Xiong et al., 2011), o que pode ser responsável pela perda óssea associada à ausência de carga.

A expressão de esclerostina é diminuída pela carga mecânica (Robling et al., 2008). Diversos estudos em animais demonstraram níveis de esclerostina inversamente proporcionais à massa óssea (Staehling-Hampton et al., 2002; MacDonald et al., 2007; Li et al., 2008; Wijenayaka et al., 2011).

Um ganho profundo de massa óssea foi observado após a supressão de SOST, resultando no desenvolvimento de anticorpos monoclonais anti-esclerostina como um potencial tratamento para a osteoporose. Estudos em animais e primeiros resultados de ensaios clínicos parecem muito promissores e sugerem que esse anticorpo possa representar uma terapêutica eficaz para aumentar a massa óssea (Ominsky et al., 2011; Tian et al., 2011). 
Na Odontologia, Jäger et al. (2010) demonstraram a presença de esclerostina em cementócitos e osteócitos por meio de imunohistoquímica em cortes histológicos de dentes e osso alveolar de camundongos e humanos.

Além disso, Lehnen e colaboradores (2012) demonstraram a expressão de esclerostina no tecido periodontal (cemento, ligamento periodontal e osso alveolar) em camundongos recém-nascidos, bem como em animais com 1, 2, 4 e 8 semanas de idade. Embora nenhuma marcação para esclerostina tenha sido observada nas fases iniciais de cementogênese, foi possível detectá-la em camundongos com 4 e 8 semanas de idade. Os autores concluíram que, uma vez que a imunomarcação para esclerostina não pôde ser detectada nas fases iniciais da formação do cemento, o papel desta proteína parece estar relacionado com a homeostase do tecido e o seu processo de cicatrização.

Outra proteína expressa por osteócitos é a proteína regulada por oxigênio 150 (ORP150). Ela é uma chaperona, ou seja, uma proteína que têm por função assistir outras proteínas, a qual tem sido recentemente estudada por desempenhar um papel importante na adaptação celular à hipóxia e na prevenção de apoptose celular em vários tipos de tecidos. Esta proteína é associada ao retículo endoplasmático e está presente em osteócitos maduros, embebidos na matriz óssea mineralizada (Montesi et al., 2016).

A ORP150 é induzida por diversos estímulos, incluindo hipóxia, isquemia, privação de glicose, agentes redutivos, estresse no retículo endoplasmático e outras funções, como mecanismo de sobrevivência (Aleshin et al., 2005). Além disso, estudos demonstram que sua expressão se apresenta aumentada em vários tumores clinicamente isolados e linhagens celulares de cânceres (Miyagi et al., 2002; Stojadinovic et al., 2007).

\section{MÉtodos de AVALIAÇÃo dos OsteóctTos}

A localização dos osteócitos no interior do tecido ósseo torna o estudo dessas células tecnicamente difícil, representando até hoje um desafio ainda não totalmente superado (Halleux et al., 2012; Stern et al., 2012; Kalajzic et al., 2013; Stern e Bonewald, 2015). Até o momento, há diversos grupos de pesquisa no mundo avaliando diferentes protocolos para a otimização do isolamento dessas células de tecidos mineralizados permitindo, assim, o seu estudo.

Algumas linhagens celulares osteocyte-like como a MLO-Y4 (osteócitos maduros) e a MLO-Y5 (osteoblastos tardios/osteócitos jovens) têm sido amplamente estudadas na tentativa de elucidação da participação dos osteócitos em diversos processos fisiológicos e patológicos, além dos seus mecanismos de sinalização (Kato et al., 1997; Dallas et al., 2009; Wei et al., 2015). 
Modelos de estudo nos quais os osteócitos encontrem-se "deletados" ou reduzidos são apontados na literatura como uma forma de análise de suas funções (Komori et al., 2014). Dentre os modelos animais descritos na literatura, pode-se destacar o uso de um camundongo transgênico (Cre-DPM1 GJA1 conditional knockout), o qual apresenta deleção seletiva da conexina 43, no qual o sistema de comunicação intracelular dos osteócitos é interrompido, mas o sistema de comunicação extracelular através dos canalículos está intacto (Bivi et al., 2012a). Nesse modelo animal, a apoptose de osteócitos apresenta-se aumentada (Komori, 2014).

Um outro modelo encontrado na literatura caracteriza-se pelo uso de camundongos transgênicos para $B C l-2$, com superexpressão desse gene em osteoblastos. Neste animal, observa-se a apoptose de osteócitos consequente da redução dos seus processos dendríticos e da alteração do citoesqueleto celular. De fato, há uma necrose "secundária", entretanto, não ocorre reação inflamatória. Nesse tipo de animal, a osteoclastogênese e a reabsorção óssea são reduzidas, indicando que os osteócitos estimulam a reabsorção óssea e a osteoclastogênese em condições fisiológicas (Moriishi et al., 2012).

Em adição, é possível encontrar na literatura estudos demonstrando efeito colateral em células do tecido ósseo após o uso de uma classe de drogas sensibilizadoras de insulina (Sorocéanu et al., 2004; Ali et al., 2005; Di Paola et al., 2006; Hassumi et al., 2009; Mabilleau et al., 2010; Broulík et al., 2011; Mieczkowska et al., 2011).

Essas drogas são denominadas Tiazolidinedionas (TZDs), também conhecidas como glitazonas, e compreendem três medicamentos: a Rosiglitazona, a Troglitazona e a Pioglitazona. Tratam-se de fármacos bem tolerados pelo organismo e popularizados no tratamento do diabetes tipo 2. Entretanto, alguns efeitos colaterais têm sido relatados como aumento de peso, retenção de líquidos, risco aumentado de insuficiência cardíaca congestiva (Dormandy et al., 2005; Kahn et al., 2006), ocorrência de fraturas ósseas em mulheres (Mabilleau et al., 2010), diminuição da formação e da densidade mineral óssea (Ali et al., 2005; Broulík et al., 2011) e aumento da apoptose de osteócitos (Sorocéanu et al., 2004; Mabilleau et al., 2010; Mieczkowska et al., 2011).

A Rosiglitazona e a Pioglitazona são drogas agonistas dos receptores ativados por proliferadores de peroxissoma gama (PPAR-y). Um novo papel na manutenção da homeostase óssea vem sendo atribuído para esses receptores - a regulação da osteclastogênese, observada em camundongos (Wan et al., 2007).

Sabe-se que adipócitos e osteócitos são originados das mesmas células progenitoras. Uma vez ativadas pelo RUNX2, seguem sua diferenciação para uma linhagem de osteoblastos, enquanto que a ativação pelo PPAR-y leva ao desenvolvimento de adipócitos. 
Como os TZDs são agonistas dos PPAR-y, foi postulado que esses medicamentos aumentam a diferenciação de adipócitos, em detrimento de osteoblastos in vitro (Lecka-Czernik et al., 1999; 2002).

Uma vez que foi relatado que os TZDs aumentam significantemente a apoptose de osteócitos e a expressão da esclerostina (Mabilleau et al., 2010), estudos empregando os TZDs para indução medicamentosa de apoptose de osteócitos têm sido realizados (Sorocéanu et al., 2004; Di Paola et al., 2006; Hassumi et al., 2009).

Após a morte do osteócito, o espaço lacunar é mantido até o momento em que a área do osso é substituída durante o processo de remodelação. Desta forma, a detecção microscópica do osteócito apoptótico deve ser realizada com cautela. Dentre as técnicas para esta detecção mais comumente descritas na literatura, podemos citar a observação de lacunas vazias em cortes histológicos, a avaliação por meio da técnica de TUNEL (transferase-mediated dUTP nick-end labeling) e a imunomarcação de caspase-3 (Jilka et al., 2013). Adicionalmente, a identificação de células apoptóticas também pode ser realizada pela coloração 4,6'-diamino-2-fenilindol (DAPI). Essa substância é capaz de penetrar as membranas celulares e corar a cromatina, a qual se apresenta muito condensada em células apoptóticas (Salvador, 2009). Foi relatado na literatura o uso das técnicas de TUNEL e DAPI como técnicas complementares na avaliação de células apoptóticas (Li et al., 2016).

Diante do exposto, observa-se que novas evidências sugerem que os osteócitos participam de diferentes fases de desenvolvimento do tecido ósseo (Rochefort et al., 2010; Atkins e Findlay, 2012). Entretanto, há a necessidade de estudos acerca da participação dessas células e dos seus marcadores em patologias da cavidade bucal como a lesão periapical.

\section{OS CEMENTócItos}

Assim como os osteócitos, os cementócitos também ocupam lacunas e apresentam dendritos dentro de um sistema lacunocanalicular, como descrito em alguns estudos em cemento celular de camundongos (Cao et al., 2012; Zhao et al., 2016).

O cementoblasto é um tipo celular localizado no cemento, o qual recobre a superfície radicular do dente, onde as fibras estão inseridas. São células que participam da proteção radicular contra reabsorções, uma vez que são isentas de receptores específicos (Cho et al., 1991). No cemento celular, presente nos terços médio e apical do dente, à medida que se formam novas camadas de cemento, alguns cementoblastos são incluídos na matriz cementária, comportando-se fenotipicamente como os osteócitos.

A origem dos cementoblastos permanece controversa, com uma clássica hipótese apontando para células ectomesenquimais do folículo dentário e outra hipótese alternativa 
proposta mais recentemente que sugere que as células da bainha epitelial de Hertwig sofrem transformação epitelial-mesenquimal e contribuem para a origem de cementoblastos (Bosshardt, 2005; Foster e Somerman, 2012). Apesar desta incerteza, é amplamente assumido que os cementoblastos que produzem o cemento celular tornam-se os cementócitos embutidos na matriz extracelular.

A comparação entre a regulação e a diferenciação de cementoblastos e osteoblastos, in vivo, bem como a composição de suas respectivas matrizes, revela que elas têm muito em comum (Bosshardt, 2005). Por exemplo, os elementos encontrados tanto na diferenciação de osteoblastos como de cementoblastos do cemento celular são indicados pelos efeitos da mutação genética e deleção de reguladores de osteoblastos chave como Runx2 e Osterix (Camilleri e McDonald, 2006; Cao et al., 2012).

É possível encontrar na literatura estudos que descrevem distinções entre cementócitos e osteócitos em termos de dendritos, lacunas e canalículos. Em estudo apresentando análise tridimensional de cementócitos humanos por microscopia confocal de varredura a laser foi indicado um comprimento médio de corpo celular de 9 a $17 \mu \mathrm{m}$, semelhante ao estimado para osteócitos de calvária de filhotes de aves (10-15 $\mu \mathrm{m})$, embora o número de dendritos por célula seja significativamente diferente entre os tipos de células (Scivetti et al., 2007). Considerando que os cementócitos apresentam cerca de 8 a 20 dendritos por célula, os osteócitos estendem um número estimado de dendritos de 40 a mais de 100, dependendo da espécie estudada (Beno et al., 2006; Dallas et al., 2013). Em concordância com este fato, a rede canalicular dos cementócitos é consideravelmente menos densa e aparenta ser menos organizada, levando a áreas de cemento com poucos canalículos (Kagayama et al., 1997; Zhao et al., 2016).

Lacunas vazias (e algumas com remanescentes nucleares ou materiais fibrilares) são observadas no cemento celular profundo, sugerindo a morte celular através de um mecanismo desconhecido. Acredita-se que a duração de vida de um osteócito é ditada pela taxa de turnover ósseo e, como tal, pode continuar por décadas. No cemento celular, onde não há remodelação fisiológica significativa, os cementócitos são embutidos durante toda a vida e, com o tempo e aposição contínua de cemento, pode-se exceder a distância para a troca eficaz de nutrientes (Zhao et al., 2016).

Alguns autores sugerem que o cemento seja um tipo de osso avascular, não-inervado e que não está sujeito ao processo de remodelação fisiológica. Entretanto, o cemento é provavelmente o tecido mineralizado menos compreendido e pouco se sabe com relação às vias de sinalização envolvidas nas patologias cementárias mediadas por cementócitos (Foster, 2012). 
Além disso, pouco se sabe sobre receptores expressos por cementócitos. No entanto, verifica-se que os cementócitos expressam receptores para endotelinas, neuroquininas e peptídeo 1 relacionado com o gene da calcitonina (Vandevska-Radunovic et al., 2003; Neuhaus e Byers, 2007). Ainda não está claro se os cementócitos desempenham qualquer papel na direção do metabolismo sistêmico dos minerais e parece improvável que eles possam ter um efeito significativo em comparação com o grande número de osteócitos que expressam FGF23 e outros fatores.

Alguns estudos in vivo com a marcação de corantes vitais de lacunas de cementócitos e canalículos sugerem sua participação na calcificação secundária de matriz cementóide (Kagayama et al., 1997). Além disso, foi sugerido que os cementócitos participam da "cementólise", ou reabsorção do cemento perilacunar (Bielaczyc e Gołebiewska, 1997).

Um recente trabalho realizado pelo nosso grupo de pesquisa relata que os cementócitos expressam RANKL em resposta à infecção endodôntica em dentes de camundongos (De Rossi et al., 2016). Embora o cemento não esteja submetido à remodelação fisiológica, pode-se esperar que mecanismos envolvidos na reabsorção óssea sejam similares aos envolvidos na reabsorção de cemento devido a semelhanças com o tecido ósseo, como por exemplo, durante a instalação e progressão da lesão periapical.

\section{A Lesão Periapical}

A lesão periapical desenvolve-se a partir da invasão bacteriana no tecido pulpar, a qual desencadeia um processo inflamatório, podendo levar à necrose deste tecido. Inicialmente, o processo apresenta prevalência de micro-organismos Gram-positivos aeróbios (Fabricius et al., 1982) entretanto, devido a fatores como o comprometimento sanguíneo em decorrência da necrose pulpar, a pouca disponibilidade de nutrientes e a baixa tensão de oxigênio, ocorre uma alteração no perfil bacteriano, que passa a apresentar predominância de micro-organismos anaeróbios estritos, particularmente os Gram-negativos (Assed et al., 1996; Rocha et al., 2008; Mohammadi, 2011).

A permanência desse processo resulta na instalação de uma reação infecciosa crônica, caracterizada pelo desequilíbrio entre o número e virulência dos micro-organismos presentes no sistema de canais radiculares, com relação à resistência do hospedeiro (Sjögren et al., 1997). Essa reação inflamatória envolve o recrutamento e a ativação de diferentes tipos celulares, como a ativação de células endoteliais, neutrófilos, macrófagos, linfócitos e osteoclastos, que contribuem para a ocorrência da reabsorção óssea na região periapical (Graves et al., 2011). 
Até o presente momento, não há relato de pesquisas sobre o papel desempenhado pelos osteócitos e seus marcadores durante o processo de instalação e progressão de lesões periapicais.

Assim, para abordar o tema proposto, foram desenvolvidos estudos divididos nos 2 capítulos a seguir:

1. Rosiglitazona estimula a apoptose de osteócitos, interferindo no desenvolvimento de lesões periapicais induzidas em camundongos

2. Apoptose de cementócitos ocorre fisiologicamente e estimulada pelo uso sistêmico de medicamento agonista do receptor ativado por proliferador de peroxissoma 


\section{Capítulo 1}

Rosiglitazona estimula a apoptose de osteócitos, interferindo no desenvolvimento de lesões periapicaís induzidas em camundongos 



\section{INTRODUÇÃO}

A lesão periapical desenvolve-se a partir da invasão bacteriana no tecido pulpar, a qual desencadeia um processo infeccioso e imunoinflamatório crônico, resultando em reabsorção nos tecidos apicais e periapicais. Esta é caracterizada por um desequilíbrio entre o número e a virulência dos micro-organismos presentes no sistema de canais radiculares, com relação a resistência do hospedeiro (Sjögren et al., 1997). O processo imunoinflamatório nas lesões de origem endodôntica envolve a participação de diferentes tipos celulares como a ativação de células endoteliais, neutrófilos, macrófagos, linfócitos e osteoclastos, que contribuem simultaneamente para a destruição do tecido ósseo (Graves et al., 2011).

Os osteócitos, que representam o tipo celular mais abundante no tecido ósseo (aproximadamente $95 \%$ das células presentes) foram, por muito tempo, considerados células estáticas ou inativas, com interesse fisiológico e patológico limitado, sendo caracterizadas muitas vezes apenas por sua morfologia e localização e poucas vezes por sua função (Dallas et al., 2013). A localização dos osteócitos, embebidos na matriz óssea mineralizada, torna o estudo dessas células tecnicamente difícil, o que representa até hoje um desafio ainda não totalmente superado (Neve et al., 2012; Stern et al., 2012; Halleux et al., 2012; Kalajzic et al., 2013; Stern e Bonewald, 2015).

Os osteócitos são considerados os orquestradores de muitas funções ósseas, já que são indispensáveis para a homeostase do esqueleto adulto (Dallas et al., 2013) e contribuem para a regulação da disponibilidade de cálcio no esqueleto maduro pela extração deste mineral do espaço peri-lacunar (Atkins e Findlay, 2012). Além disso, são considerados os iniciadores e o centro do processo de remodelação óssea (Tate et al., 2004; Rochefort et al., 2010), sendo os principais responsáveis pela expressão de RANKL (citocina ativadora da osteoclastogênese) e de esclerostina (proteína inibidora de osteoblastos) (O'Brien et al., 2013).

A proteína esclerostina, transcrita pelo gene Sost, está relacionada com a diferenciação de osteoblastos em osteócitos maduros através da regulação de PHEX (gene fosfato-regulador com homologia a endopeptidase no cromossomo $X$ ) e MEPE (fosfoglicoproteína da matriz extracelular) (Winkler et al., 2003; Atkins et al., 2011). Além disso, a esclerostina estimula a osteoclastogênese pelo aumento da expressão de RANKL (Wijenayaka et al., 2011).

Além da esclerostina, dentre as proteínas expressas por osteócitos, podemos destacar também a proteína da matriz dentinária 1 (DMP1) e a proteína regulada por oxigênio 150 
(ORP150), dentre outras. A DMP1 foi originalmente identificada nos dentes como uma proteína da matriz extracelular ácida (George et al., 2003) e posteriormente foi identificada como sendo altamente expressa em odontoblastos e osteoblastos/osteócitos (Feng et al., 2003).

Por sua vez, a ORP150 tem sido recentemente estudada por desempenhar um papel importante na adaptação celular à hipóxia e na prevenção de apoptose celular em vários tipos de tecidos. Esta proteína está presente em osteócitos maduros, embebidos na matriz óssea mineralizada (Montesi et al., 2016).

Efeitos colaterais em células do tecido ósseo têm sido relatados após o uso de uma classe de medicamentos indicados para o tratamento do diabetes melitus tipo 2 , as Tiazolidinedionas (TZDs) (Sorocéanu et al., 2004; Ali et al., 2005; Di Paola et al., 2006; Hassumi et al., 2009; Mabilleau et al., 2010; Mieczkowska et al., 2011). A Rosiglitazona, pertencente a essa classe de drogas, é um agonista sintético com alta afinidade pelo receptor ativado por proliferador de peroxissoma PPAR-y (Peroxisome proliferator-activated receptor- $\gamma$ ). Esse receptor está envolvido na diferenciação de células progenitoras em adipócitos ou em osteoblastos, os quais posteriormente podem sofrer diferenciação dando origem a osteócitos. Assim, o uso contínuo da Rosiglitazona pode estimular a apoptose de osteócitos (Sorocéanu et al., 2004; Mabilleau et al., 2010; Mieczkowska et al., 2011). Entretanto, até o presente momento, o efeito da apoptose de osteócitos estimulada pela Rosiglitazona na formação e progressão da lesão periapical não foi estudado.

Dessa forma, os objetivos do presente trabalho foram avaliar, in vivo, (1) um protocolo de administração sistêmica da Rosiglitazona em camundongos a fim de estimular a apoptose de osteócitos em maxilares; e (2) a formação e a progressão de lesões periapicais em diferentes períodos experimentais (7, 21 e 42 dias) induzidas em dentes de camundongos wild type (C57BL/6) que receberam ou não a Rosiglitazona.

\section{MATERIAL E MÉTODOS}

Todos os procedimentos realizados nos animais foram conduzidos de acordo com as diretrizes éticas da Comissão de Ética no Uso de Animais da Universidade de São Paulo Campus de Ribeirão Preto (Processo no 2014.1.450.58.8; Anexo A) e baseados no guia ARRIVE para o relato de estudos em animais (Kilkenny et al., 2010).

Foram utilizados camundongos machos da linhagem C57BL/6, com 4 a 5 semanas de idade, pesando em média 15 gramas, adquiridos do Biotério Central da Universidade de São Paulo - Campus de Ribeirão Preto. Os animais foram mantidos em gaiolas de polipropileno 
(5 animais por gaiola), com temperatura $\left(22 \pm 2^{\circ} \mathrm{C}\right)$ e umidade relativa do ar $(55 \pm 10 \%)$ constantes, em ciclo de claro escuro de 12:12 horas, mantidos no Biotério I da Faculdade de Odontologia de Ribeirão Preto - USP, com livre acesso à ração e água.

\section{Etapa 1: Definição de um PRotocolo de AdMInISTRAÇÃo SistêMICA da Rosiglitazona PARA ESTIMULAR A APOPTOSE DE OSTEÓCITOS EM MAXILARES}

Para esta etapa foram utilizados 24 camundongos, os quais foram divididos em 4 grupos (1 grupo controle e 3 grupos experimentais) e submetidos ou não aos efeitos da Rosiglitazona (Sigma-Aldrich Ltda, São Paulo, Brasil). Os animais foram randomizados de forma simples (usando uma tabela de números aleatórios).

O protocolo de administração foi baseado em estudos prévios (Sorocéanu et al., 2004; Ali et al., 2005; Di Paola et al., 2006; Hassumi et al., 2009) sendo, portanto, utilizada a via de administração oral (gavagem, volume final de $165 \mu \mathrm{L} /$ animal/dose), na dose de $10 \mathrm{mg} / \mathrm{kg}$ de peso do animal (PBS + 10\%DMSO, como veículo) diariamente (1 dose/dia), durante 1, 2 ou 3 semanas, com o objetivo de identificar o melhor período de administração da Rosiglitazona capaz de estimular a apoptose de osteócitos de maneira mais expressiva nos maxilares. A tabela 1 apresenta a distribuição dos grupos experimentais de acordo com a solução administrada e períodos de administração do medicamento.

Tabela 1. Distribuição dos grupos experimentais e períodos de avaliação

\begin{tabular}{c|c|c} 
Grupos & Solução administrada & Período de administração \\
G1 & Veículo (PBS + 10\% DMSO) (Controle) & 1 semana \\
\hline G2 & Rosiglitazona (10 $\mathrm{mg} / \mathbf{k g})+$ PBS + 10\% DMSO & 1 semana \\
\hline G3 & Rosiglitazona (10mg/kg) + PBS + 10\% DMSO & 2 semanas \\
\hline G4 & Rosiglitazona (10mg/kg) + PBS + 10\% DMSO & 3 semanas \\
\hline
\end{tabular}

\section{PROCESSAMENTO HISTOTÉCNICO}

Após os períodos de administração da Rosiglitazona para cada grupo, foi aguardado um período de 42 dias, com o objetivo de simular um período tardio de avaliação da lesão periapical, e os animais foram mortos por meio de anestesia instramuscular com cloridrato de Ketamina (Ketamina 10\% - $150 \mathrm{mg} / \mathrm{Kg}$ de peso - Agener União Química Farmacêutica Nacional S/A, Embu-Guaçu, SP, Brasil) e Xilazina $2 \%-7,5 \mathrm{mg} / \mathrm{Kg}$ de peso - Dopaser, Laboratórios Calier S.A, Barcelona, Espanha), e inalação de $\mathrm{CO}_{2}$ em câmara específica. Após a eutanásia, as mandíbulas foram removidas com tesoura cirúrgica esterilizada e divididas na região de incisivos. As hemi-arcadas foram fixadas por imersão em formol tamponado a $10 \%$ por 24 horas à temperatura ambiente e lavadas por aproximadamente 4 horas em água 
corrente. Em seguida, para a descalcificação das peças, foi utilizada solução à base de EDTA a 4,13\% (pH 7-7,4). As peças foram mantidas nesta solução, à temperatura ambiente e trocada semanalmente até sua completa descalcificação, o que ocorreu após um período de aproximadamente 30 dias. 0 grau de descalcificação das estruturas mineralizadas foi testado por meio da penetração de uma agulha nos tecidos, para verificação da sua consistência. Após esse procedimento, as peças foram submetidas ao processamento histotécnico de rotina, que inclui lavagem em água corrente por 2 horas, desidratação em álcool de concentrações crescentes (70\% e 95\% por 30 minutos cada; 2 trocas de $100 \%$ por 20 minutos cada e 2 trocas de álcool $100 \%$ por 40 minutos cada), diafanização em xilol (2 banhos de 20 minutos e 1 de 40 minutos) e inclusão em parafina. Os blocos contendo as hemi-mandíbulas foram cortados longitudinalmente em micrótomo (Leica RM2145; Leica Microsystems $\mathrm{GmbH}$, Wetzlar, Alemanha) no sentido mésio-distal. Cortes semi-seriados de $5 \mu \mathrm{m}$ foram obtidos incluindo os primeiros e segundos molares e o tecido ósseo alveolar. Por amostra, foram obtidas de 10 a 15 lâminas, com 3 cortes em cada lâmina (Silva et al., 2012; Oliveira et al., 2015).

\section{MÉTODO DO TUNEL}

O método do TUNEL [ Terminal Deoxynucleotidyl Transferase-mediated Deoxyuridine Triphosphate (dUTP) Nick-end Labeling] foi realizado com a utilização de um kit para detecção de fragmentos de DNA derivado de células em apoptose (Apop Tag-Plus Kit Oncor Inc., Gaithersburg, Maryland, EUA) de acordo com o protocolo do fabricante. Os cortes foram pré-tratados em $20 \mu \mathrm{g} / \mathrm{ml}$ de proteinase $\mathrm{K}$ (Oncor-Protein Digesting Enzyme) durante 15 minutos a $37^{\circ} \mathrm{C}$ e, após diversas lavagens em água destilada, foram imersos em peróxido de hidrogênio a 3\% em PBS (fosfato de sódio a $50 \mathrm{mM}, \mathrm{pH} 7,4, \mathrm{NaCl}$ a $200 \mathrm{mM}$ ) durante 15 minutos, e em seguida imersos em tampão de equilíbrio específico do kit. Após incubação em enzima TdT (desoxinucleotidil transferase termina) a $37^{\circ} \mathrm{C}$ durante 1 hora em câmara humidificada, a reação foi interrompida por imersão em tampão de parada/lavagem a $37^{\circ} \mathrm{C}$ durante 15 minutos. Em seguida, os cortes foram lavados em PBS durante 10 minutos e incubados em anti-digoxigenina-peroxidase a $37^{\circ} \mathrm{C}$ durante 1 hora, em câmara humidificada. Após lavagem em PBS, os cortes foram tratados com solução de $0,06 \%$ de tetracloridrato de 3,38-diaminobenzidina (Sigma, St. Louis, Missouri, EUA) na presença de peróxido de hidrogênio a $0,1 \%$ durante 5 a 10 minutos, à temperatura ambiente. Os cortes foram contracorados com hematoxilina. Como controle positivo foram utilizadas lâminas com cortes de glândulas mamárias provenientes do kit. Os controles negativos foram obtidos por omissão da enzima TdT (Cerri et al., 2000). 


\section{COLORAÇÃo DE DAPI}

A coloração 4'-6-diamidino-2-fenilindol (DAPI) foi utilizada para analisar a condensação de DNA. Os cortes desparafinados foram lavados três vezes com PBS por cinco minutos cada, impermeabilizados com PBS-Triton a 0,5\% e lavados novamente três vezes com PBS por cinco minutos cada. Em seguida, foram incubados com $0,25 \mu \mathrm{g} / \mathrm{ml}$ do corante DAPI em PB (tampão fosfato) durante aproximadamente cinco minutos, à temperatura ambiente, em ambiente escuro.

\section{QuANTIFICAÇÃo de CÉlULAS APOPTótiCAS}

Todas as análises foram realizadas em microscópio óptico convencional (Carl Zeiss MicroImaging $\mathrm{GmbH}$, Göttingen, Alemanha). Os dados foram analisados por um único examinador experiente, cegos para os grupos. Nenhum filtro foi utilizado para a análise de TUNEL, enquanto que um filtro azul de microscópio específico (DAPI, Carl Zeiss MicroImaging $\mathrm{GmbH}$, Göttingen, Alemanha) foi utilizado para a visualização das lâminas coradas com DAPI. Foram analisados de cinco a seis campos microscópicos aleatórios tanto no osso alveolar entre os molares como abaixo dos ápices dos mesmos nas mandíbulas de cada animal para contagem de células (ampliação de 630x). A razão de osteócitos apoptóticos/osteócitos totais em cada campo foi calculada, utilizando-se o software Image J (1,49u National Institutes of Health, EUA). Foi calculada a média das razões de dois cortes para cada animal, e os valores de todos os animais por grupo em cada período de administração do medicamento foram considerados para análise estatística (Moin et al., 2014).

Foram considerados osteócitos TUNEL-positivos as células coradas com cor castanha, apresentando desintegração ou fragmentação do núcleo (Gavrieli et al., 1992). Os osteócitos DAPI-positivos foram considerados quando seus núcleos apresentavam manchas fluorescentes definidas, indicando a condensação de DNA no núcleo (Chu et al., 2014; Chiu et al., 2015). Os resultados foram expressos como porcentagem média de osteócitos apoptóticos/osteócitos totais ( \pm desvio padrão) para cada grupo.

\section{etapa 2: Avaliação da formação e Progressão de lesões Periapicais induzidas em CAMUNDONGOS QUE RECEBERAM OU NÃO a ROSIGLITAZONA}

\section{INDUÇÃO dAS LESÕES PERIAPICAIS}

Em uma segunda etapa do estudo, após a definição do melhor período experimental de administração da Rosiglitazona para indução de apoptose de osteócitos em maxilares 
(Rosiglitazona na dose de 10mg/kg + PBS + 10\%DMSO, 1 vez ao dia) por 2 semanas, foram induzidas lesões periapicais nos primeiros molares inferiores de 60 camundongos. Os animais foram anestesiados, via intramuscular, com cloridrato de Ketamina (Ketamina 10\% - 150 mg/Kg de peso - Agener União Química Farmacêutica Nacional S/A, Embu-Guaçu, SP) e Xilazina 2\% - 7,5mg/Kg de peso (Dopaser, Laboratórios Calier S.A, Barcelona, Espanha), previamente à realização dos procedimentos operatórios. Para permitir adequada visualização e fácil acesso aos molares inferiores, foi utilizada uma mesa cirúrgica específica, na qual os animais foram posicionados permitindo a manutenção da abertura bucal e correta visualização dos dentes.

Um modelo clássico para indução de lesão periapical em roedores foi empregado (Kawashima e Stashenko, 1999; Sasaki et al., 2004; De Rossi et al., 2008; Silva et al., 2012; De Oliveira et al., 2015). Os tecidos pulpares dos primeiros molares inferiores (esquerdo e direito) dos camundongos foram expostos à microbiota da cavidade bucal com auxílio de broca dental esférica em baixa rotação (no 1/4 - KG Sorensen) (Figura 1A) acoplada a peça de mão elétrica montada em motor de baixa rotação e contra-ângulo (Dabi Atlante Equipamentos Odontológicos, Ribeirão Preto, SP, Brasil) até que a entrada de acesso aos canais radiculares fosse visualizada e verificada com uma lima endodôntica tipo $\mathrm{K}$ número 8 (Maillefer S/A, Suíça) (Figura 1B). Em seguida, os dentes permaneceram expostos à cavidade bucal para favorecer a contaminação pela microbiota bucal. Após os períodos experimentais de 7, 21 e 42 dias, os animais foram submetidos à eutanásia por meio de anestesia intramuscular com Ketamina e Xilazina e inalação de $\mathrm{CO}_{2}$ em câmara específica. Os animais $(n=60)$ foram randomizados de forma simples (usando uma tabela de números aleatórios) e divididos em seis grupos, de acordo com a administração da Rosiglitazona $(10 \mathrm{mg} / \mathrm{kg}+\mathrm{PBS}+10 \% \mathrm{DMSO})$ ou não (PBS+10\%DMSO) e do período de evolução da lesão periapical (7, 21 ou 42 dias): G1) veículo +lesão 7 dias; G2) veículo + lesão 21 dias; G3) veículo + lesão 42 dias; G4) TZD + lesão 7 dias; G5) TZD + lesão 21 dias; G6) TZD + lesão 42 dias.

Tabela 2. Distribuição dos grupos experimentais e períodos de progressão da lesão periapical.

\section{Grupos} Solução administrada
Período de progressão da lesão periapical

\begin{tabular}{c|c|c} 
G1 & Veículo (PBS + 10\% DMSO) (Controle) por 1 semana & $\mathbf{7}$ dias \\
\hline G2 & Veículo (PBS + 10\% DMSO) (Controle) por 1 semana & $\mathbf{2 1}$ dias \\
\hline G3 & Veículo (PBS + 10\% DMSO) (Controle) por 1 semana & $\mathbf{4 2}$ dias \\
\hline G4 & Rosiglitazona (10mg/ $\mathbf{k g})+$ PBS + 10\% DMSO por 2 semanas & $\mathbf{7}$ dias \\
\hline G5 & Rosiglitazona $(10 \mathrm{mg} / \mathbf{k g})+$ PBS + 10\% DMSO por 2 semanas & $\mathbf{2 1}$ dias \\
\hline G6 & Rosiglitazona (10 $\mathrm{mg} / \mathbf{k g})+$ PBS + 10\% DMSO por 2 semanas & $\mathbf{4 2}$ dias \\
\hline
\end{tabular}


Após a eutanásia dos animais, as mandíbulas foram removidas com tesoura cirúrgica esterilizada e divididas na região de incisivos, obtendo-se duas hemi-arcadas. As hemimandíbulas esquerdas foram submetidas a processamento histotécnico, enquanto que as hemimandíbulas direitas foram armazenadas em solução de RNA later para posterior avaliação por meio da técnica de RT-PCR.

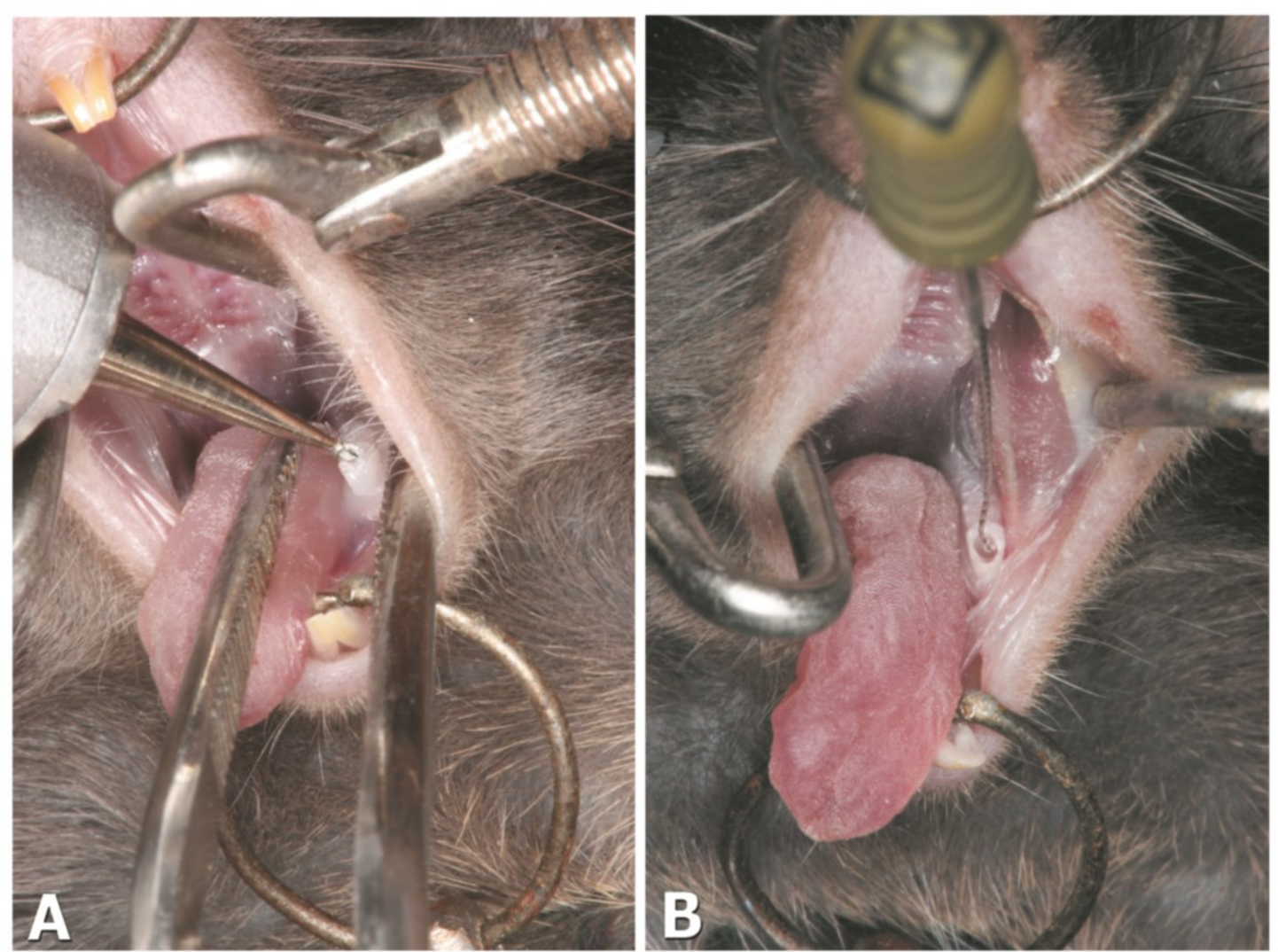

Figura 1. A) Abertura coronária dos primeiros molares inferiores com broca esférica em baixa rotação, até que a entrada de acesso aos canais radiculares fosse visualizada e B) verificação da entrada dos canais radiculares com uma lima endodôntica tipo $\mathrm{K}$ número 8.

\section{PRocessamento Histotécnico e AVALIAÇÃo MiCRoscópica}

As hemimandíbulas esquerdas foram fixadas por imersão em formol tamponado a $10 \%$ por 24 horas à temperatura ambiente e lavadas por, aproximadamente, 4 horas em água corrente. Em seguida, as peças foram submetidas a processamento histotécnico de rotina, conforme previamente descrito.

Inicialmente, os cortes representativos de cada grupo experimental foram corados com hematoxilina e eosina (HE) e submetidos à análise em microscopia óptica convencional para descrição da região apical e periapical. Paralelamente, foi realizada a análise morfométrica da extensão da área das lesões periapicais em microscopia de fluorescência.

Todas as análises foram realizadas por um único avaliador experiente, sem conhecimento prévio do grupo a ser analisado, em microscopia óptica convencional, 
empregando-se o microscópio Axio Imager.M1 (Carl Zeiss MicroImaging GmbH, Göttingen, Alemanha) com câmera AxioCam MRc5 acoplada (Carl Zeiss MicroImaging GmbH, Göttingen, Alemanha). Foram avaliadas as raízes distais dos primeiros molares inferiores, em cortes mostrando simultaneamente os terços coronário, médio e apical do canal radicular, o forame apical e o osso alveolar.

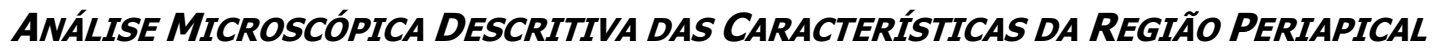

A análise descritiva da região apical e periapical foi realizada nos cortes representativos corados em HE de cada período e de cada grupo experimental, avaliando-se principalmente o ligamento periodontal, o cemento apical (características das lacunas da superfície) e o osso alveolar (presença de reabsorção e características das lacunas).

\section{MORFOMETRIA EM MICROSCOPIA DE FLUORESCÊNCIA}

Conforme descrito por De Rossi et al. (2007), a avaliação morfométrica das lesões periapicais foi realizada nos espécimes corados com HE utilizando-se o microscópio Axio Imager.M1, em aumento de 10x, operando no modo fluorescente - filtro Alexa Fluor 488 (AF488, Carl Zeiss MicroImaging GmbH, Göttingen, Alemanha) - com as seguintes características: excitação de G365, refletores FT395 e emissão LP420. A área das lesões periapicais foram delineadas e medidas em $\left(\mu \mathrm{m}^{2}\right)$ em software específico para uso com este microscópio (AxioVision Rel, versão 4.8, Zeiss). Foram avaliados de 2 a 3 cortes centrais de cada espécime, obtendo-se a média para cada animal. A delimitação da lesão excluiu as estruturas intactas (ligamento periodontal, cemento e osso alveolar), facilmente identificadas pela forte fluorescência verde, assim como incluiu áreas de reabsorção, dissociação fibrilar e infiltrado inflamatório, identificadas pela ausência de fluorescência e aparência escurecida.

\section{histoenzimologia para a Atividade da fosfatase Ácida Resistente aO tartarato (TRAP)}

A atividade da TRAP foi utilizada para a marcação de células gigantes multinucleadas. Os cortes foram desparafinados ( 2 banhos de xilol de 5 minutos cada) e hidratados (álcool $100 \%$ por duas vezes de cinco minutos cada; alcoóis 95\%, 70\% e 50\% por dois minutos cada e água destilada pelo mesmo período). A seguir, as lâminas foram colocadas em solução de álcool/acetona a 50\% durante um minuto e os cortes foram secos à temperatura ambiente. Em seguida, uma solução contendo $10 \mathrm{~mL}$ de tampão de ácido acético, $0,1 \mathrm{~mL}$ de dimetilformamida, $5 \mathrm{mg}$ de Fast-red e $1 \mathrm{mg}$ de ácido fosfórico naftol AS-BI (Sigma-Aldrich Corporation, Saint Louis, EUA) foi pipetada sobre os cortes, que permaneceram protegidos 
da luz, em estufa a $37^{\circ} \mathrm{C}$, pelo tempo suficiente para se observar a marcação (aproximadamente 1 minuto). Após a incubação, foi realizada a contra-coloração com Fast Green por 1 minuto. A seguir, as lâminas foram montadas e avaliadas em microscópio Axio Imager.M1 sob luz convencional para contagem do número de células TRAP-positivas presentes em lacunas de reabsorção em contato direto com o osso alveolar ao redor da lesão periapical, sendo expressas em número absoluto de células.

\section{TÉCNICA DE ABSORTOMETRIA RADIOLÓGICA DE DUPLA ENERGIA (DXA)}

Após a realização da eutanásia, os fêmures dos animais de todos os grupos foram removidos cirurgicamente. Um fêmur de cada animal foi analisado por meio do densitômetro de absorbância de raios-X de energia dual Lunar PIXImus (Lunar PIXImus Corp. Headquarters, Madison, WI, USA), para registro da Densidade Mineral Óssea (DMO), em $\mathrm{g} / \mathrm{cm}^{2}$ da metáfise distal dos fêmures. Os dados obtidos foram registrados e analisados pelo software Lunar PIXImus, (versão 2.2, Lunar PIXImus Corp. Headquarters), conforme descrito por Lucisano e colaboradores (2013). Os grupos foram comparados entre si com o objetivo de investigar se a administração da Rosiglitazona afetou ou não a DMO dos ossos longos.

\section{RT-PCR: ANÁLISE DA EXPRESSÃo GÊNICA DE MARCADORES DE OSTEÓCITOS}

\section{ISOLAMENTO E PURIFICAÇÃo doS Á́cIdOS NuClÉICOS}

Após a dissecação das mandíbulas, as hemi-arcadas destinadas à avaliação da expressão gênica foram utilizadas para extração do RNA total. As amostras foram maceradas e submetidas a kit específico para o isolamento dos ácidos nucléicos (PureLink RNA Mini Kit, Ambion, Life Technologies, Carlsbad, CA, EUA). Os procedimentos foram realizados de acordo com o protocolo do fabricante. O conteúdo de RNA extraído foi mensurado em espectrofotômetro com comprimento de onda de 260nm. Posteriormente, o RNA foi transformado em DNA complementar (cDNA) pela ação da transcriptase reversa com o uso de kit específico (High Capacity cDNA Reverse Transcription Kit, Applied Biosystems, Lituânia).

\section{Reação em Cadeia da Polimerase em Tempo Real}

Nesta etapa foram avaliados os RNAs mensageiros (RNAm) de Dmp1 (gene que codifica a DMP1), Sost (gene que codifica a esclerostina) e Hyou1 (gene que codifica a ORP150) diferencialmente expressos entre os grupos. Foram utilizados primers para a 
amplificação dos genes-específicos no PCR em tempo real (Applied Biosystems, Foster City, California, EUA) e os genes constitutivos Gapdh (que codifica a enzima gliceraldeído-3fosfato desidrogenase) e o Actb (que codifica a $\beta$-actina) foram utilizados como genes de referência.

A quantificação do produto resultante do PCR em tempo real foi realizada por meio da adição do reagente SYBR $^{\circledR}$ Green (Applied Biosystems, Foster City, California, EUA). Todas as reações de PCR em tempo real foram realizadas em duplicata. A expressão gênica relativa foi determinada a partir da expressão dos genes constitutivos. O cálculo da diversidade entre os produtos gerados pelo PCR foi feita com auxílio do método $\{2-\Delta(\Delta \mathrm{Ct})\}$.

\section{ANÁLISE ESTATÍSTICA}

Todas as análises estatísticas (de ambas as etapas) foram realizadas utilizando-se 0 software Graph Pad Prism 4 (Graph Pad Software Inc., San Diego, CA, EUA). Foi estabelecido um nível de significância de $5 \%$ para todas as análises. Uma vez que os dados apresentaram distribuição normal (comprovado pelo teste de Shapiro-Wilk), o teste one-way ANOVA foi utilizado, seguido do pós-teste de comparações múltiplas mais adequado, sugerido pelo software (Sidak ou Tukey). Para a etapa 1 do estudo, foram realizadas comparações entre todos os grupos avaliados. Para a etapa 2, foram realizadas comparações entre os grupos de animais que não receberam a Rosiglitazona (G1, G2 e G3) nos diferentes períodos de progressão da lesão periapical, comparações entre os grupos de animais que receberam a Rosiglitazona (G4, G5 e G6) nos diferentes períodos de progressão da lesão, além de comparações entre os períodos experimentais (7, 21 e 42 dias) para todas as análises.

\section{RESULTADOS}

\section{etapa 1: Definição de um Protocolo de Admintstração Sistêmica da Rosiglitazona PARA ESTIMULAR A APOPTOSE DE OSTEÓCITOS EM MAXILARES}

Inicialmente foi realizado um estudo para definição do período de administração da Rosiglitazona a ser utilizado, para posterior indução das lesões periapicais.

O grupo controle mostrou significativamente menor proporção de osteócitos apoptóticos/osteócitos totais quando comparado aos grupos experimentais, independentemente da técnica avaliada (TUNEL ou DAPI) (Figura 2).

Os cortes corados pelo método TUNEL mostraram aproximadamente $17 \%(0,174 \pm$ $0,04)$ de osteócitos TUNEL-positivos no grupo controle, $56 \%(0,565 \pm 0,07)$ de osteócitos 
TUNEL-positivos no grupo que recebeu uma semana de administração da Rosiglitazona, 66\% $(0,661 \pm 0,06)$ de osteócitos TUNEL-positivos no grupo que recebeu duas semanas de administração da Rosiglitazona e 70\% $(0,705 \pm 0,02)$ de osteócitos TUNEL-positivos no grupo que recebeu três semanas de administração da Rosiglitazona (Figura 3-A).

Os cortes corados pelo método DAPI mostraram aproximadamente $22 \%(0,223 \pm$ $0,10)$ de osteócitos DAPI-positivos no grupo controle, $35 \%(0,355 \pm 0,03)$ de osteócitos DAPI-positivos no grupo que recebeu uma semana de administração da Rosiglitazona, 49\% $(0,491 \pm 0,11)$ de osteócitos DAPI-positivos no grupo que recebeu duas semanas de administração da Rosiglitazona e 38\% $(0,380 \pm 0,01)$ de osteócitos DAPI-positivos no grupo que recebeu três semanas de administração da Rosiglitazona (Figura 3-B).

A figura 3 ilustra a comparação entre os grupos. É possível observar diferença estatisticamente significante entre o grupo controle (G1) e todos os outros grupos. Além disso, houve diferença entre o grupo que recebeu a Rosiglitazona por uma semana (G2) e o grupo que recebeu a Rosiglitazona por duas semanas $(G 3)(p<0,05)$ porém sem diferença significante entre o grupo que recebeu o medicamento por duas semanas (G3) e o grupo que o recebeu por três semanas (G4) (Figura 3).

Assim, foi selecionado o período de 2 semanas de administração da Rosiglitazona para ser utilizado na etapa 2 do presente estudo, anteriormente à indução de lesões periapicais em molares inferiores de camundongos.
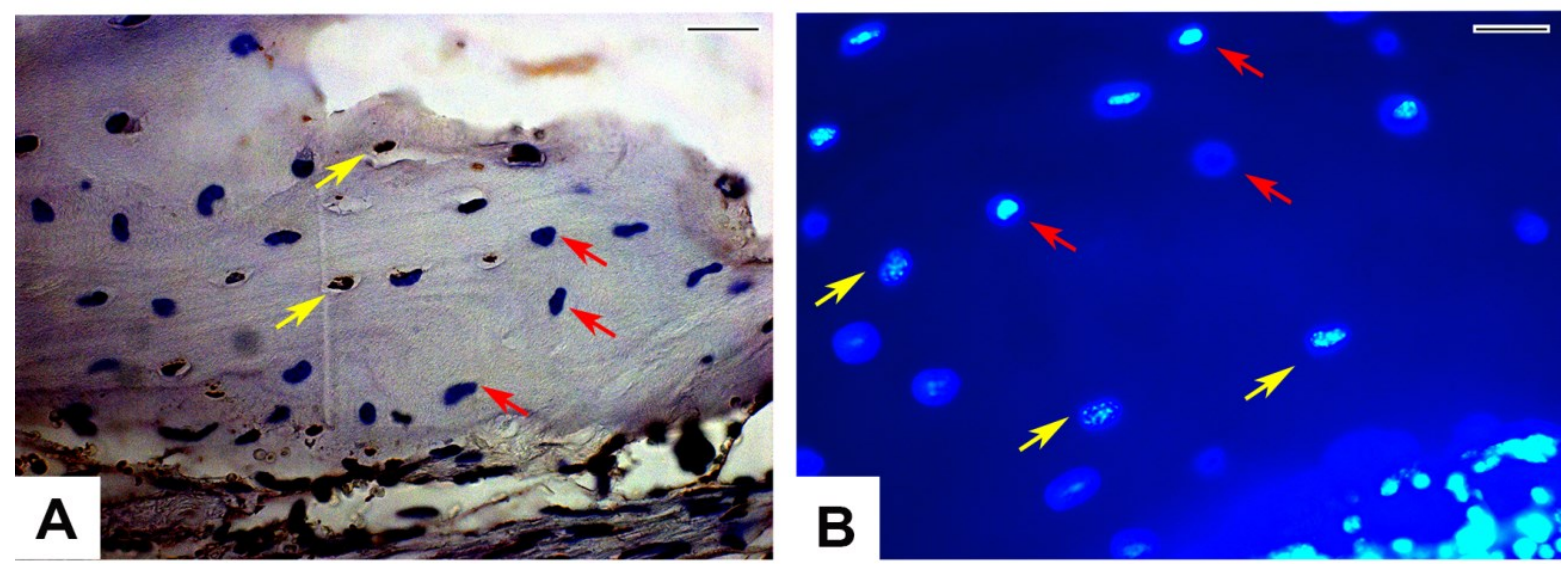

Figura 2. A) Imagem representativa do Grupo G3 (que recebeu a Rosiglitazona durante 2 semanas) pelo método TUNEL. As setas vermelhas indicam osteócitos não apoptóticos, com núcleos hígidos e coloração azul. As setas amarelas indicam osteócitos apoptóticos, com coloração acastanhada. B) Imagem representativa do Grupo G3 (que recebeu a Rosiglitazona durante 2 semanas) pela técnica DAPI. As setas vermelhas indicam osteócitos não apoptóticos, com núcleos hígidos (homogeneamente fluorescentes ou sem fluorescência), enquanto as setas amarelas indicam áreas de DNA condensadas nos núcleos celulares, vistas por pontos fluorescentes definidos, em osteócitos apoptóticos. Barra no canto superior direito das figuras $=20 \mu \mathrm{m}$. 


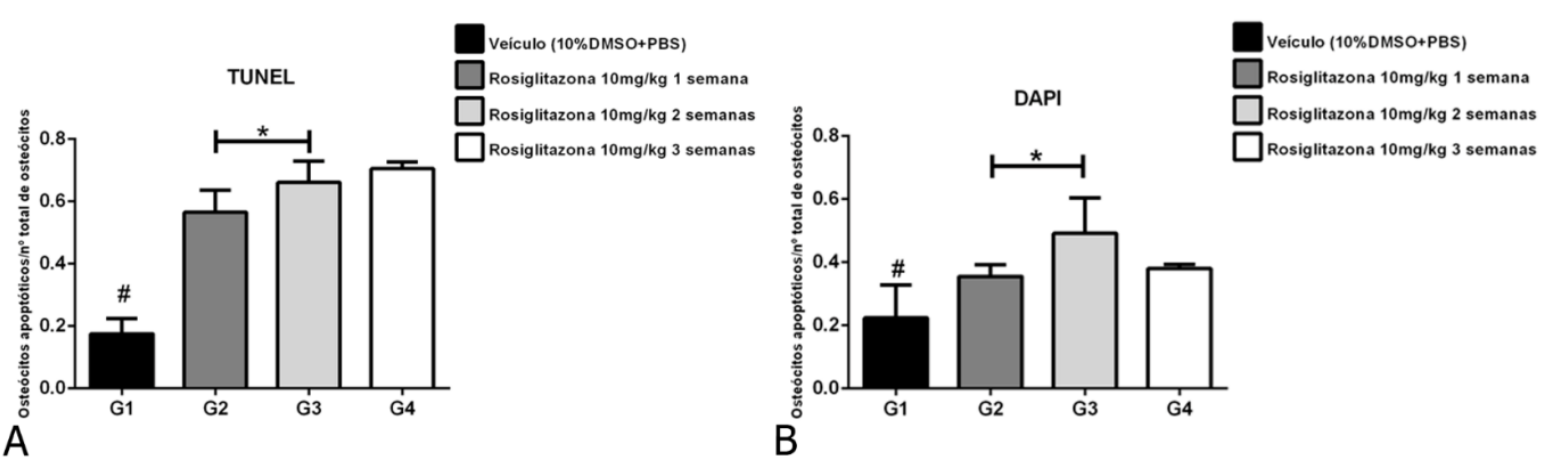

Figura 3. Representação gráfica dos osteócitos apoptóticos/osteócitos totais nos grupos controle e experimentais (1, 2 ou 3 semanas de administração da Rosiglitazona), respectivamente, avaliados pela técnica TUNEL (A) e pela técnica DAPI (B). \# indica diferença estatisticamente significante entre o G1 e todos os demais grupos. * indica diferença estatisticamente significante entre os grupos G2 e G3 $(p<0,05)$.

\section{etapa 2: Avaliação da formação e Progressão de Lesões Periapicais Induzidas em}

\section{CAMUNDONGOS QUE RECEBERAM OU NÃO A ROSIGLITAZONA}

\section{análise Microscópica Descritiva das Regiões Apical e PeRIapical}

Nos grupos que receberam apenas o veículo foi possível observar que, decorridos 7 dias da abertura coronária e consequente contaminação do canal radicular, a superfície cementária radicular apresentava-se regular, sem áreas de reabsorção; o ligamento periodontal estava suavemente aumentado e com células inflamatórias eventuais, predominantemente mononucleadas. O osso alveolar era normal. No grupo de 21 dias, 0 cemento apical apresentava-se ligeiramente irregular devido a áreas com lacunas de reabsorção na superfície e com presença de algumas lacunas vazias ou com restos necróticos. O ligamento periodontal apresentava-se aumentado, com áreas de edema, dissociação de fibras colágenas e células inflamatórias predominantemente mononucleadas. O osso alveolar apresentava áreas de reabsorção na sua superfície. Por sua vez, aos 42 dias, a superfície do cemento apresentava extensas áreas de reabsorção, o ligamento periodontal estava amplamente aumentado, com presença de infiltrado inflamatório misto e denso, osso alveolar com presença de áreas de reabsorção e ligamento periodontal bastante aumentado (Figura 4 A, C e E).

Nos grupos que receberam a Rosiglitazona por duas semanas, aos 7 dias, também foi possível observar regularidade na superfície do cemento, presença de poucas células inflamatórias e osso alveolar regular. Aos 21 dias, pôde-se observar diversas áreas de reabsorção cementária e de osso alveolar, com a presença de osteoclastos nas lacunas de reabsorção. Aos 42 dias, o ligamento periodontal encontrava-se severamente ampliado, com presença de extensas áreas de edema, dissociação fibrilar e células inflamatórias predominantemente mononucleadas. A superfície do cemento apresentava diversas áreas de 
reabsorção com a presença de algumas lacunas vazias. O osso alveolar apresentava-se severamente reabsorvido, com presença de osteoclastos nas lacunas de reabsorção e bastante distante do ápice, devido à presença do processo inflamatório na região periapical (Figura 5 A, C e E).

\section{MORFOMETRIA EM MICROSCOPIA DE FLUORESCÊNCIA}

As lâminas submetidas à coloração por hematoxilina e eosina foram observadas em microscópio de fluorescência para mensuração da área das lesões periapicais formadas nos diferentes períodos experimentais.

Nos grupos controle pôde-se observar um aumento gradativo, em $\mu \mathrm{m}^{2}$, no tamanho das lesões no decorrer dos períodos de 7, 21 e 42 dias após a indução experimental. Os valores médios da área das lesões foram $65042,21 \mu \mathrm{m}^{2}, 110623,76 \mu \mathrm{m}^{2}$ e 294696,22 $\mu \mathrm{m}^{2}$, respectivamente. A análise estatística realizada por meio do teste one-way ANOVA e pósteste de comparações múltiplas de Sidak demonstrou diferença estatisticamente significante entre os períodos de 7 e 42 dias $(p<0,05)$ e 21 e 42 dias $(p<0,05)$ (Figura 4 B, D e F).

Em relação aos grupos de animais que receberam a Rosiglitazona, os valores médios da área das lesões foram 66501,52 $\mu \mathrm{m}^{2}, 169480,66 \mu \mathrm{m}^{2}$ e 328520,37 $\mu \mathrm{m}^{2}$, respectivamente, para os períodos de 7, 21 e 42 dias. Nestes grupos, também foi observado que a progressão das lesões periapicais ao longo dos períodos experimentais apresentou um padrão tempodependente. Foi encontrada diferença estatisticamente significante pelo pós-teste de comparações múltiplas de Sidak também entre os períodos de 7 e 42 dias $(p<0,05)$ e 21 e 42 dias $(p<0,05)$ (Figura 5 B, D e F). 


\section{Grupos Veículo}
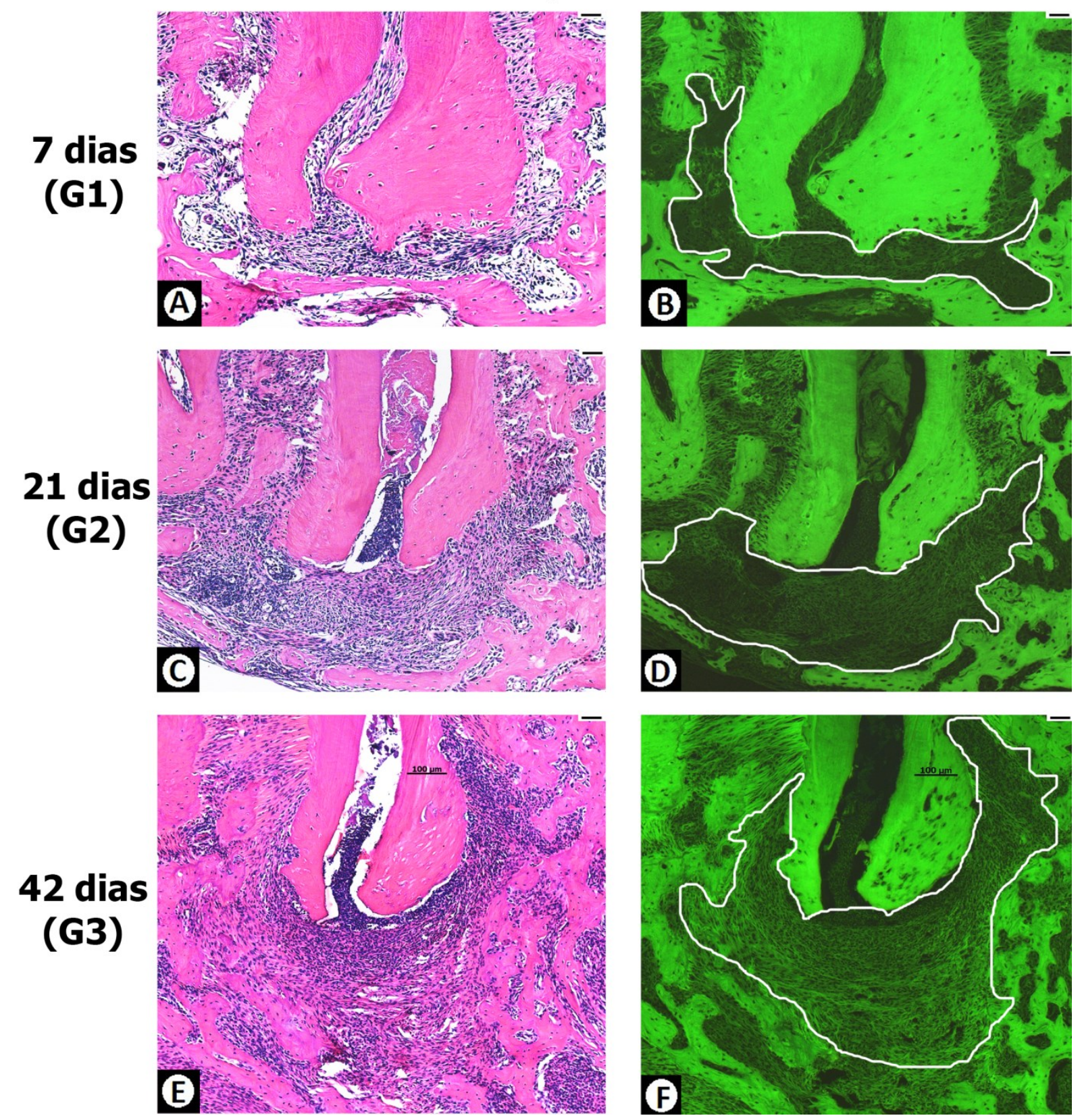

Figura 4. Fotomicrografias de cortes microscópicos representativos da mensuração das lesões periapicais em animais dos grupos controle, que receberam a administração apenas do veículo (PBS+10\%DMSO), nos períodos experimentais de 7 dias (A e B); 21 dias (C e D); e 42 dias (E e F). Os cortes foram corados com hematoxilina e eosina e observados em microscópico óptico $(\mathbf{A}, \mathbf{C}, \mathbf{E})$ e no modo fluorescente $(\mathbf{B}, \mathbf{D}, \mathbf{F})$ para análise descritiva da região periapical e para mensuração das lesões periapicais, respectivamente (HE ZEISS 10x). (G1: veículo + lesão aos 7 dias; G2: veículo + lesão aos 21 dias; G3: veículo + lesão aos 42 dias). Barra no canto superior direito de cada fotomicrografia=50 $\mu \mathrm{m}$ ). 


\section{Grupos Rosiglitazona}

7 dias (G4)
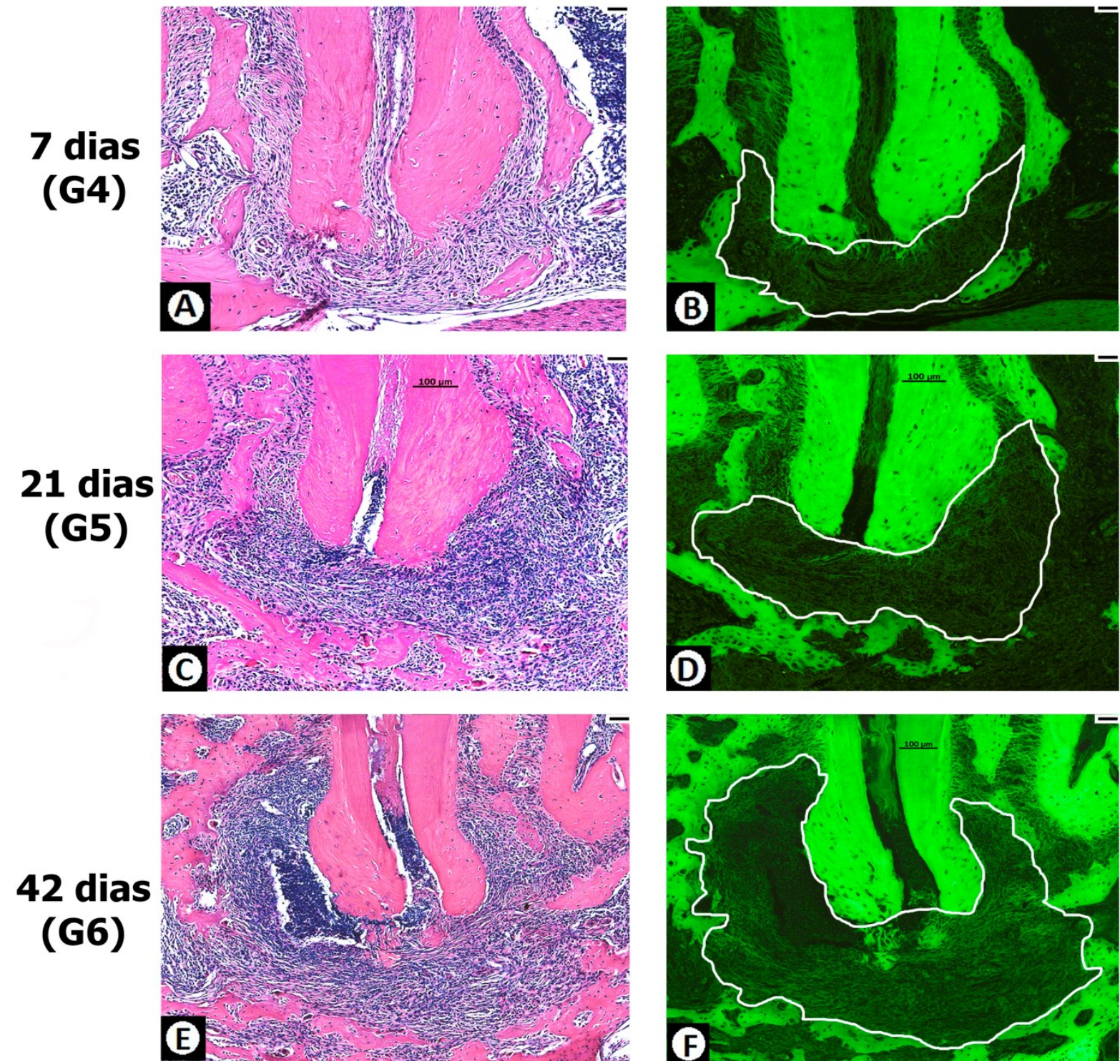

Figura 5. Fotomicrografias de cortes microscópicos representativos da mensuração das lesões periapicais em animais que receberam a administração da Rosiglitazona, nos períodos experimentais de 7 dias (A e B); 21 dias (C e D); e 42 dias (E e F). Os cortes foram corados com hematoxilina e eosina e observados em microscópico óptico (A, C, E) e no modo fluorescente (B, D, F) para análise descritiva da região periapical e para mensuração das lesões periapicais, respectivamente (HE ZEISS 10x). (G4: Rosiglitazona + lesão aos 7 dias; G5: Rosiglitazona + lesão aos 21 dias; G6: Rosiglitazona + lesão aos 42 dias). Barra no canto superior direito de cada fotomicrografia $=50 \mu \mathrm{m}$. 
Em comparação aos grupos controle, observa-se uma tendência a lesões maiores nos grupos que receberam a Rosiglitazona, porém sem diferença estatisticamente significante $(p>0,05)$ (Figura 6).

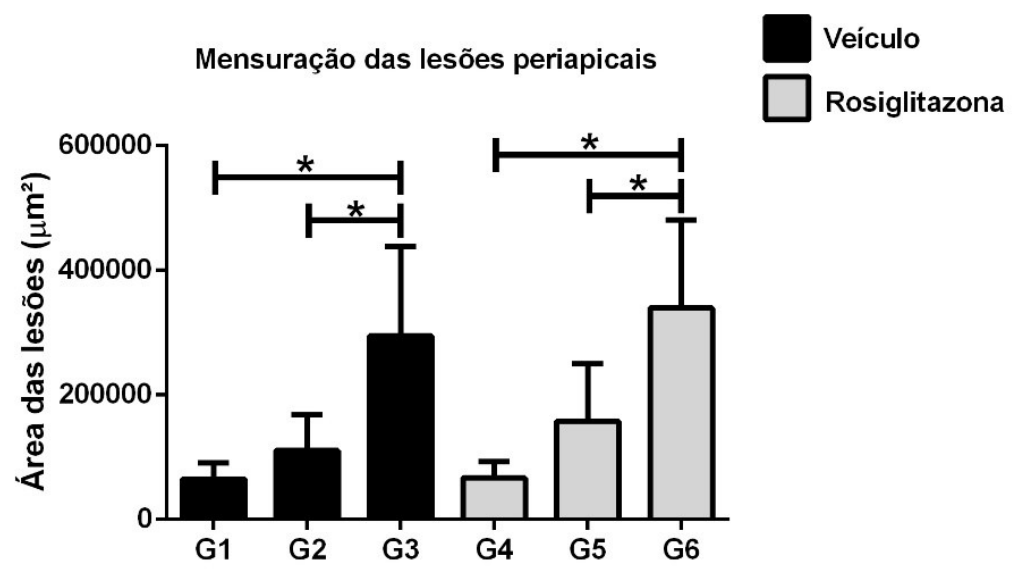

Figura 6. Representação gráfica dos valores obtidos após a mensuração das lesões periapicais induzidas experimentalmente nos animais controle e que receberam a Rosiglitazona após os períodos experimentais de 7, 21 e 42 dias. (G1: veículo + lesão aos 7 dias; G2: veículo + lesão aos 21 dias; G3: veículo + lesão aos 42 dias; G4: Rosiglitazona + lesão aos 7 dias; G5: Rosiglitazona + lesão aos 21 dias; G6: Rosiglitazona + lesão aos 42 dias). 0 asterisco representa diferença estatística $(p<0,05)$.

\section{Histoenzimologia para a Atividade da fosfatase Áctda Resistente aO taRtarato (TRAP)}

A contagem de osteoclastos foi realizada após a aplicação da técnica de histoenzimologia para a marcação da proteína fosfatase ácida resistente ao tartarato (TRAP) em lâminas obtidas dos dentes de camundongos dos grupos controle e experimentais, nos períodos de 7, 21 e 42 dias após a indução das lesões periapicais (Figura 7).

À semelhança do padrão observado na mensuração das lesões periapicais, no grupo de animais que receberam apenas o veículo (controle), observou-se aumento progressivo no número de osteoclastos com o decorrer dos períodos. A análise estatística realizada por meio do teste one-way ANOVA e pós-teste de Tukey para comparações múltiplas evidenciou diferença significante entre os períodos de 7 e 42 dias e 21 e 42 dias $(p<0,05)$ (Figura 8). Nos grupos que receberam a Rosiglitazona, também observou-se aumento progressivo no número de osteoclastos com o decorrer dos períodos, à semelhança do que ocorreu com o tamanho das lesões periapicais. A análise estatística realizada por meio do teste one-way ANOVA e pós-teste de Tukey para comparações múltiplas evidenciou diferença significante entre os períodos de 7 e 21 dias, 7 e 42 dias e 21 e 42 dias $(p<0,05)$ (Figura 8). 


\section{Veículo}

\section{7 dias}

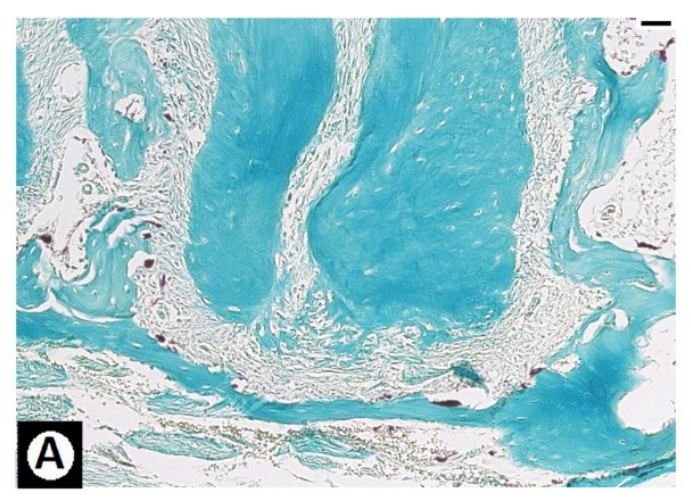

\section{1 dias}
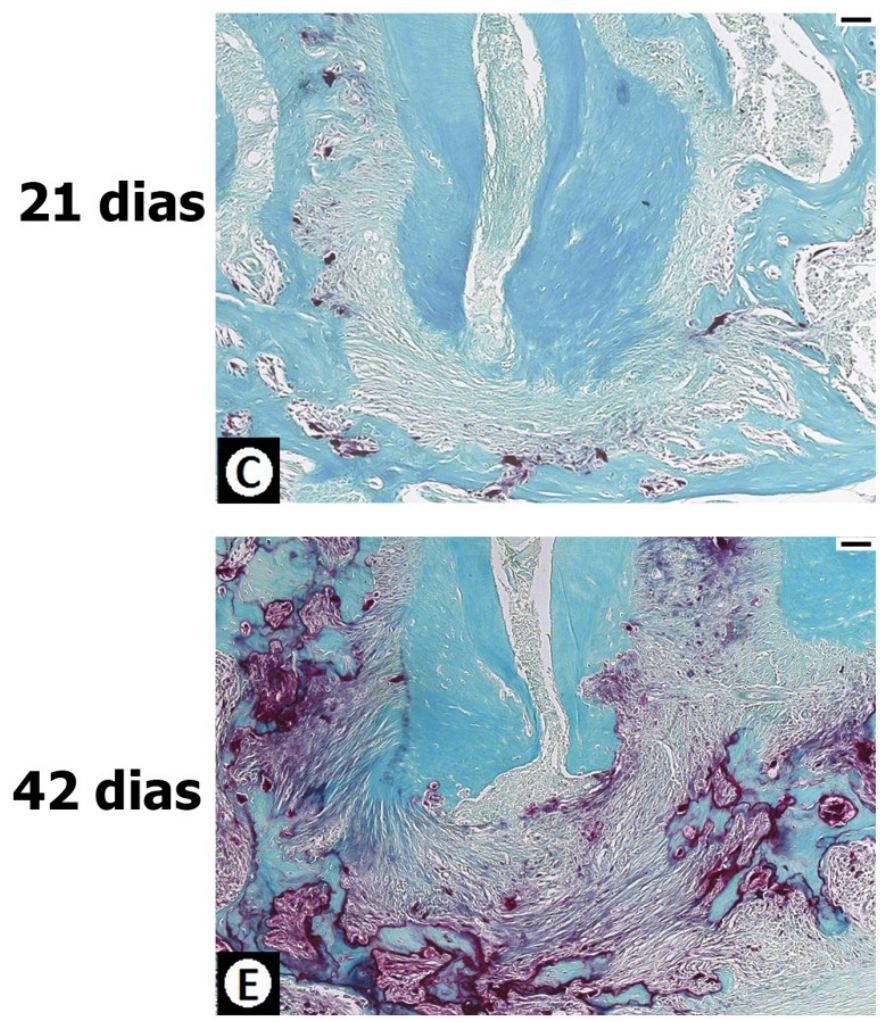

\section{Rosiglitazona}
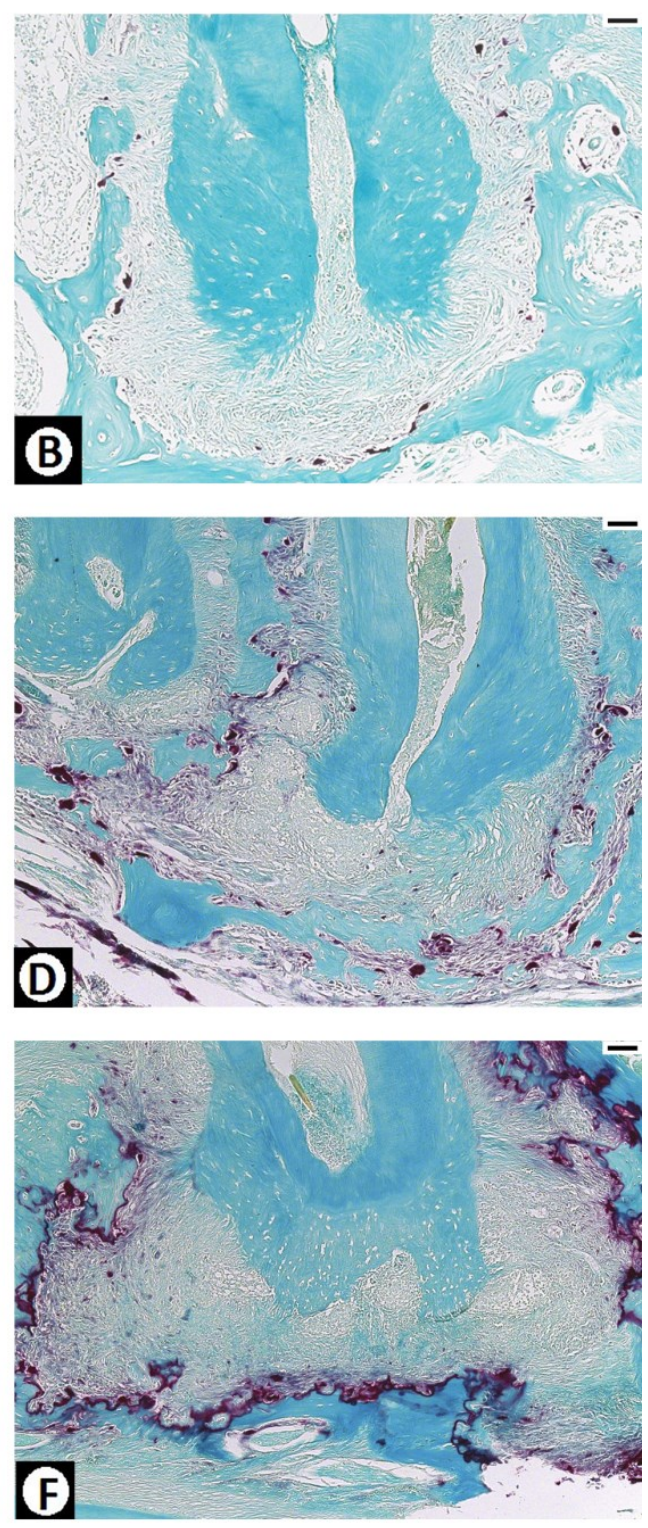

Figura 7. Fotomicrografias de cortes microscópicos representativos dos animais do grupo controle (A, C e E) e dos animais que receberam a Rosiglitazona (B, D e F), nos diferentes períodos experimentais (7, 21 e 42 dias), corados por meio da técnica de histoenzimologia para a atividade da fosfatase ácida resistente ao tartarato (TRAP), com o objetivo de identificação e contagem de células multinucleadas (osteoclastos) (HE ZEISS 10x). Barra no canto superior direito de cada fotomicrografia $=50 \mu \mathrm{m}$.

Na comparação entre os grupos de animais que receberam ou não a Rosiglitazona nos mesmos períodos experimentais, pôde-se observar semelhança no número de osteoclastos encontrados nos períodos de 7 e 42 dias ( $p>0,05)$, com aumento de acordo com a progressão da lesão periapical, apresentando diferença estatisticamente significante entre os grupos no período de 21 dias (Figura 8). 


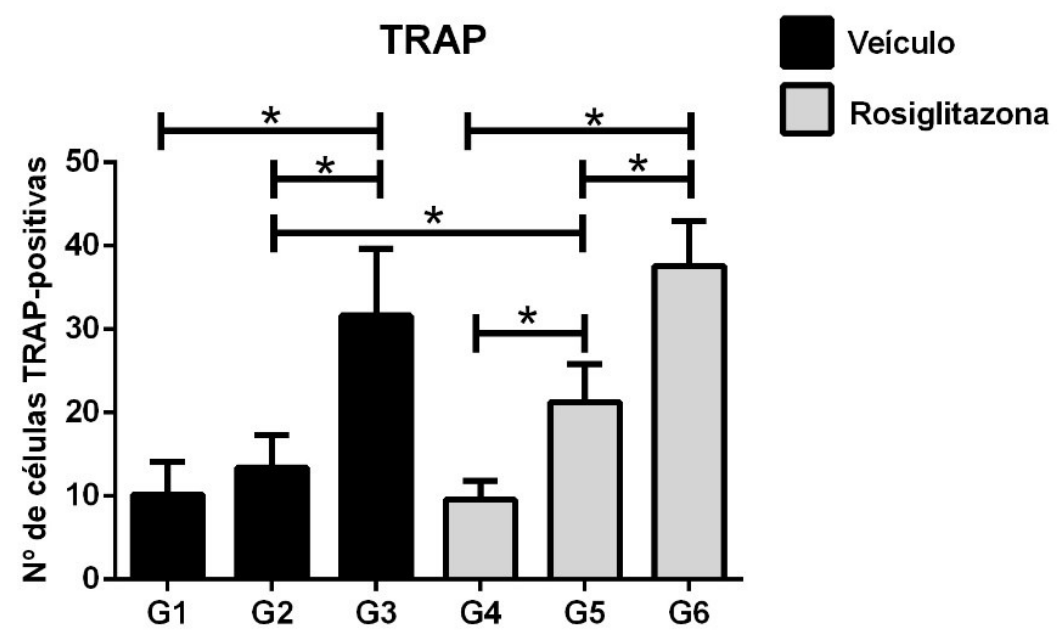

Figura 8. Representação gráfica da comparação entre os grupos da contagem de osteoclastos entre os grupos. (G1: veículo + lesão aos 7 dias; G2: veículo + lesão aos 21 dias; G3: veículo + lesão aos 42 dias; G4: Rosiglitazona + lesão aos 7 dias; G5: Rosiglitazona + lesão aos 21 dias; G6: Rosiglitazona + lesão aos 42 dias). O asterisco representa diferença estatística $(p<0,05)$.

\section{TÉCNICA DE ABSORTOMETRIA RADIOLÓGICA DE DUPLA ENERGIA (DXA)}

A Figura 9 ilustra os valores de DMO da metáfise distal dos fêmures dos camundongos obtidos por meio da técnica de DXA nos diferentes grupos controle e experimentais. Não foi possível observar diferença estatisticamente significante entre os grupos $(p>0,05)$ demonstrando que o uso sistêmico do TZD Roziglitazone por duas semanas não estimulou a apoptose de osteócitos em osso longo (fêmur).

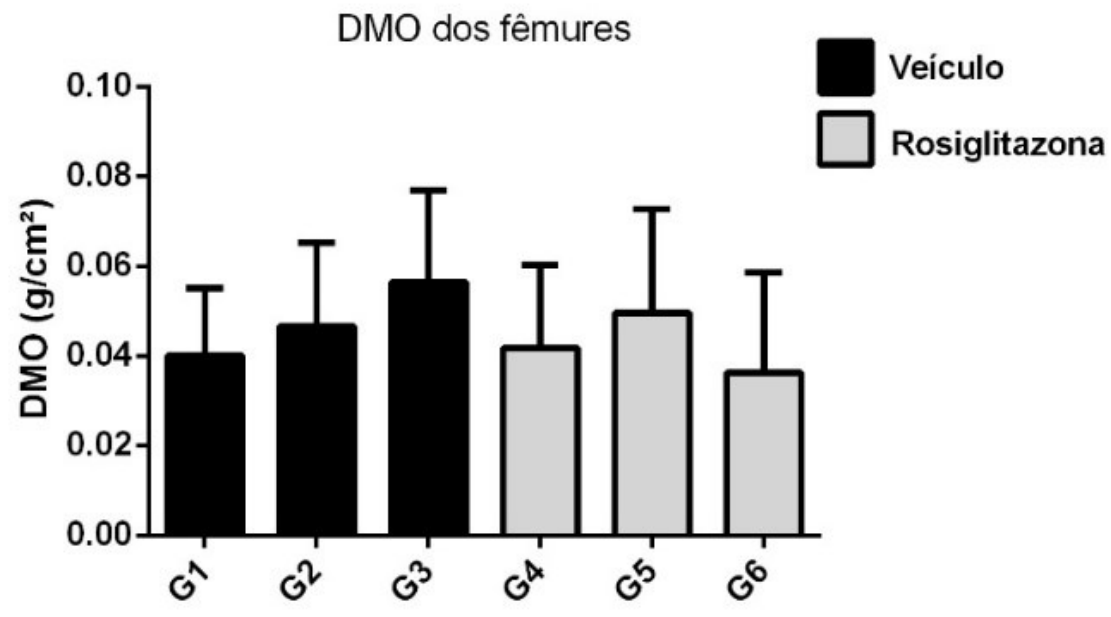

Figura 9. Representação gráfica da densidade mineral óssea $\left(\mathrm{g} / \mathrm{cm}^{2}\right)$ dos grupos de animais que receberam ou não a Rosiglitazona por duas semanas seguido de indução de lesões periapicais nos períodos de 7, 21 e 42 dias. (G1: veículo + lesão aos 7 dias; G2: veículo + lesão aos 21 dias; G3: veículo + lesão aos 42 dias; G4: Rosiglitazona + lesão aos 7 dias; G5: Rosiglitazona + lesão aos 21 dias; G6: Rosiglitazona + lesão aos 42 dias). 


\section{RT-PCR: ANÁLISE DA EXPRESSÃo GÊNICA DE MARCADORES DE OSTEÓCITOS}

Comparando-se os grupos que receberam ou não a Rosiglitazona, a análise por RTPCR demonstrou que a expressão do Sost foi maior no período de 21 dias nos camundongos que receberam o medicamento, apresentando diminuição da sua expressão de acordo com a progressão da lesão nos grupos que receberam o TZD $(p<0,05)$ (Figura 10-A).

Com relação à expressão do gene Hyou1, também foi possível observar maior expressão do mesmo na comparação entre os grupos que receberam ou não o medicamento no período de 21 dias $(p<0,05)$ (Figura 10-B).

Para o gene Dmp1, não foi possível encontrar diferença estatisticamente significante na comparação entre os grupos que receberam ou não o medicamento, entretanto observou-se diminuição da sua expressão entre os grupos de 7 e 21 dias e 7 e 42 dias nos grupos que não receberam o medicamento $(p<0,05)$ (Figura 10-C).
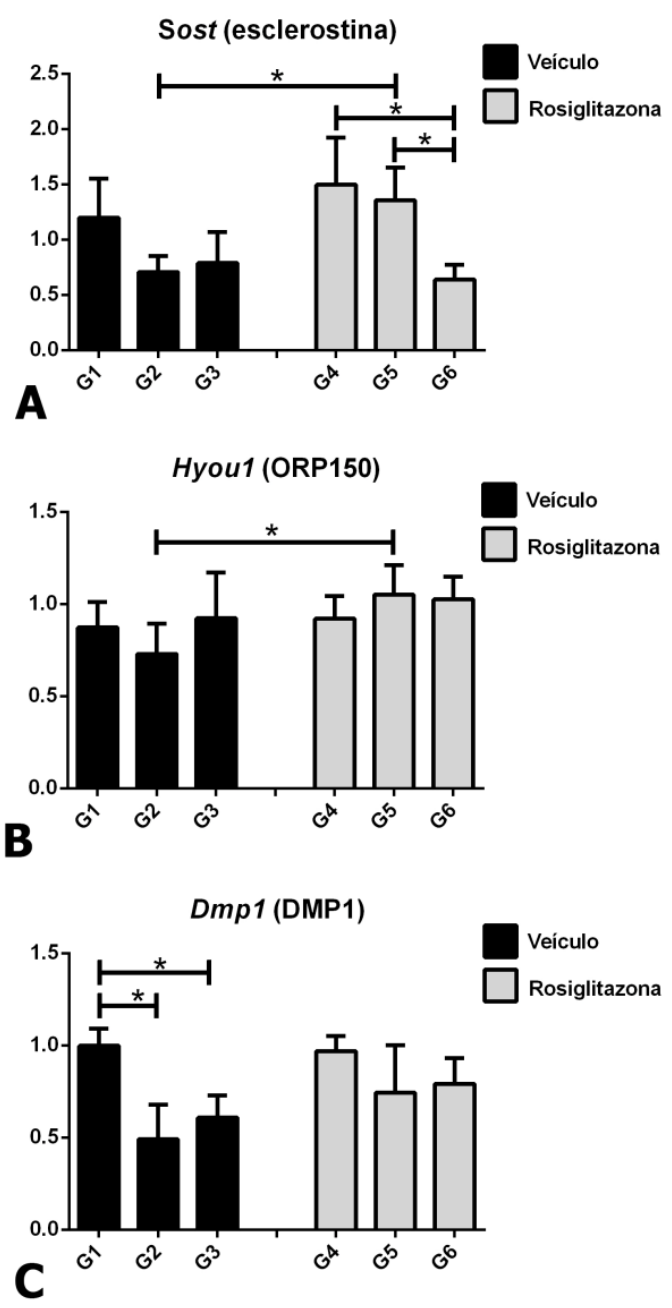

Figura 10. Representação gráfica da análise da expressão dos genes que codificam a esclerostina (Sost) (A), ORP150 (Hyou1) (B) e DMP1 (Dmp1) (C) nos animais que receberam ou não a Rosiglitazona por duas semanas seguido de indução de lesões periapicais nos períodos de 7, 21 e 42 dias. (G1: veículo + lesão aos 7 dias; G2: veículo + lesão aos 21 dias; G3: veículo + lesão aos 42 dias; G4: Rosiglitazona + lesão aos 7 dias; G5: Rosiglitazona + lesão aos 21 dias; G6: Rosiglitazona + lesão aos 42 dias). $O$ asterisco representa diferença estatística $(p<0,05)$. 


\section{DISCUSSÃO}

No presente estudo, o primeiro objetivo foi avaliar um protocolo de administração sistêmica da Rosiglitazona para estimular a apoptose de osteócitos em maxilares de camundongos. A administração da Rosiglitazona em camundongos para induzir a apoptose de osteócitos não é muito bem estabelecida na literatura e foi descrita em poucos estudos (Sorocéanu et al., 2004; Ali et al., 2005; Broulík et al., 2011). Portanto, após a realização da etapa 1 , decidiu-se realizar a administração da Rosiglitazona durante duas semanas visto que nesse período ocorreu a apoptose de osteócitos de forma mais expressiva quando comparado à administração por 1 semana, sem diferença estatisticamente significante quando comparado à administração por 3 semanas.

No presente estudo foi avaliada a progressão da lesão periapical por 7, 21 e 42 dias em camundongos que receberam ou não a Rosiglitazona durante duas semanas. A administração do TZD foi utilizada como uma forma de indução da apoptose de osteócitos, visto que esse efeito já foi relatado anteriormente na literatura (Sorocéanu et al., 2004; Mabilleau et al., 2010; Mieczkowska et al., 2011). A hipótese incial era de que os animais que receberam o TZD apresentariam lesões periapicais maiores, visto que a apoptose de osteócitos leva ao maior recrutamento de osteoclastos para a região, desencadeando maior destruição óssea (Plotkin, 2014).

Em relação ao tamanho das lesões, foi possível observar que houve um aumento gradativo, em $\mu \mathrm{m}^{2}$, no tamanho de área das lesões no decorrer dos períodos de 7, 21 e 42 dias após a indução experimental, nos grupos com e sem a administração da Rosiglitazona. Foi encontrada diferença estatisticamente significante entre os períodos de 7 e 42 dias $(p<0,05)$ e 21 e 42 dias $(p<0,05)$ quando realizadas comparações dentro dos grupos (entre os que receberam só o veículo e entre os que receberam a Rosiglitazona), entretanto, em comparação com os animais do grupo controle, observou-se uma tendência à lesões maiores nos grupos que receberam a Rosiglitazona, porém sem diferença estatisticamente significante $(p>0,05)$.

Dessa forma, destaca-se que a taxa de apoptose de osteócitos observada na mandíbula de camundongos induzida pela Rosiglitazona administrada via oral por 2 semanas não foi suficiente para alterar estatisticamente o tamanho da lesão periapical. A partir desse achado, duas hipóteses parecem surgir. A primeira, de que a apoptose dos osteócitos realmente não interfere no desenvolvimento da lesão periapical, e a segunda, de que essa taxa de apoptose de osteócitos observada no presente estudo não foi suficiente para intervir no desenvolvimento da lesão periapical. Além disso, vale destacar que a morte dos 
osteócitos poderia estimular, além de alteração no perfil das citocinas expressas por este tipo celular, mecanismos compensatórios no contexto do desenvolvimento da lesão periapical.

Foi realizada também a avaliação do número de osteoclastos presentes, adjacentes à lesão periapical. Foi possível observar que, de forma semelhante ao padrão observado na mensuração das lesões periapicais, observou-se aumento progressivo no número de osteoclastos com o decorrer dos períodos, nos animais com e sem a Rosiglitazona. $\mathrm{Na}$ comparação entre os grupos que receberam ou não o medicamento, pôde-se observar diferença estatisticamente significante no período de 21 dias, com mais osteoclastos presentes no grupo que recebeu a Rosiglitazona $(p>0,05)$. Este achado corrobora com estudos que demonstraram maior perda óssea em camundongos após a administração de TZD (Ali et al., 2005; Broulík et al., 2011) e maior osteoclastogênese. Foi sugerido que os osteócitos apoptóticos sinalizam para osteócitos vizinhos, de forma a aumentar a expressão de RANKL, o que ocasiona aumento da osteoclastogênese e da reabsorção óssea (Plotkin et al., 2014).

Apesar de não apresentar uma diferença estatisticamente significante, no período de 42 dias também foi observado um aumento no número de osteoclastos. Esse fato pode ser decorrente de que, frente à uma infecção, o organismo inicialmente responde de forma mais expressiva, na tentativa de combatê-la, seguido de um período de "acomodação" ou "adaptação" deste processo.

Em relação à avaliação da densidade mineral óssea do fêmur dos camundongos, não foi observada diferença estatisticamente significante entre os grupos apesar de uma tendência à diminuição nos grupos que receberam a Rosiglitazona $(p>0,05)$. Este achado pode ser devido ao fato de que, para que a apoptose de osteócitos apresente efeito massivo na densidade mineral óssea em ossos longos, seria necessário um maior período de administração da droga, uma vez que Broulík e colaboradores (2011) relataram uma diminuição significante da densidade mineral óssea de camundongos após a administração da Rosiglitazona durante 9 semanas, comparados com camundongos controle.

O estudo dos osteócitos ainda apresenta algumas dificuldades, como anteriormente mencionado, e o interesse no estudo dessas células foi amplamente despertado nos últimos anos (Franz-Odendaal et al., 2006; Bonewald, 2007). Alguns estudos relatam a heterogeneidade nos padrões de expressão de proteínas e genes de osteoblastos e osteócitos, levantando a possibilidade da existência de subpopulações específicas desses tipos celulares, com destinos finais diferentes (Liu et al., 1997; Candeliere et al., 2001). Assim, diversos marcadores de osteócitos têm sido descritos, como a E11/gp38, CD44, 
MEPE, PHEX, FGF-23, CapG, porém sem definição bem estabelecida com relação a proteínas expressas estritamente por osteócitos, a serem utilizadas como marcadores estritos.

Os osteócitos são uma fonte abundante de esclerostina, o principal inibidor da atividade de osteoblastos (Szczesny et al., 2015), além de estimular a formação de clastos por aumento da expressão de RANKL. A partir da avaliação por meio da técnica de RT-PCR realizada no presente estudo, foi possível observar que a expressão do Sost (gene que codifica a esclerostina) foi maior no período de 21 dias nos camundongos que receberam a Rosiglitazona, acompanhada de maior número de osteoclastos, concordando com os achados da literatura (Wijenayaka et al., 2011).

Um estudo recente avaliou a expressão da ORP150, proteína expressa por osteócitos, mediada por condições de hipóxia in vitro. Os autores relataram um aumento relativo no RNAm da ORP150, o que suporta seu papel citoprotetor em condições de privação de oxigênio (Montesi et al., 2016). À semelhança da literatura, nossos resultados demonstraram que aos 21 dias houve um aumento na expressão do gene Hyou1 (que codifica a ORP150) durante a progressão da lesão periapical. Em relação à expressão do $D m p 1$, no presente estudo não foi observada diferença significante entre os grupos que receberam ou não a administração sistêmica da Rosiglitazona. Este achado pode ser devido ao fato que de o DMP1 é considerado um marcador de osteoblastos jovens, ainda não totalmente embebidos na matriz mineralizada e, portanto, os mesmos podem não ter sofrido influência da Rosiglitazona administrada por duas semanas (Atkin et al., 2011).

Os achados do presente estudo estão de acordo com a literatura, uma vez que foi demonstrado que os TZDs apresentam efeito no aumento da osteoclastogênese (Sorocéanu et al., 2004; Wan et al., 2007; Kawashima et al., 2009), aumento na expressão de esclerostina (Mabilleau et al., 2010) e da perda óssea em camundongos por meio da supressão de osteoblastos e da formação óssea (Ali et al., 2005).

Nosso estudo não pode ser diretamente comparado com outros da literatura, uma vez que não há relatos da avaliação de osteócitos durante o desenvolvimento da lesão periapical. Entretanto, avaliando-se a participação de osteócitos em processo imuneinfeccioso, Pesce-Viglietti et al. (2015) avaliaram se a infecção por Brucella abortus modificaria a função dos osteócitos. Os autores relataram que a infecção pôde alterar a função de osteócitos, contribuindo para danos no tecido ósseo.

Assim, mais estudos são necessários nesse contexto para tentar elucidar a participação dos osteócitos durante a instalação e progressão de processos infecciosos crônicos da cavidade bucal, como na infecção endodôntica e formação da lesão periapical. 


\section{CONCLUSÃO}

A partir dos parâmetros utilizados e das metodologias realizadas, pôde-se concluir que:

- Na etapa 1, a administração sistêmica da Rosiglitazona por 2 semanas estimulou a apoptose de osteócitos de forma mais expressiva que o período de 1 semana e sem diferença significativa com o período de 3 semanas sendo, portanto, selecionado como período de administração para a etapa 2.

- Na etapa 2, a administração sistêmica da Rosiglitazona por 2 semanas interferiu na progressão das lesões periapicais induzidas em camundongos uma vez que alterou o número de osteoclastos, a expressão de Sost e Hyou1, não influenciando na expressão de Dmp1, além de tendência ao aumento do tamanho das lesões periapicais e à diminuição da DMO em ossos longos de camundongos. 



\section{Capitulo 2}

Apoptose de cementócitos ocorre físiologicamente e estimulada pelo uso sistêmíco de medicamento agonista do receptor ativado por proliferador de peroxissoma 



\section{INTRODUÇÃO}

Atualmente sabe-se que, além de desempenharem função mecano-sensorial, os osteócitos são os principais reguladores da remodelação óssea por meio da produção de fatores solúveis que atingem a medula óssea e influenciam a diferenciação e atividade de osteoblastos e osteoclastos (Xiong et al., 2011; Bellido, 2014). Dentre esses fatores, destaca-se que os osteócitos são as células que mais expressam o RANKL (ligante do receptor ativador do fator nuclear kappa-B) responsável pela indução da reabsorção óssea por meio da estimulação da diferenciação e função de osteoclastos (Kular et al., 2012; O’Brien et al, 2013).

Além disso, a morte de osteócitos é acompanhada por grandes aumentos da expressão de RANKL no tecido ósseo, o qual também desempenha um papel no aumento da reabsorção deste tecido (Tatsumi et al., 2007; O'Brien et al., 2013; Plotkin et al., 2015). O acúmulo de osteócitos apoptóticos pode ser induzido pela diminuição de esteróides sexuais, excesso de glicocorticóides, imobilização, aumento do estresse oxidativo e envelhecimento (Tomkinson et al., 1997; Weinstein et al., 2000; Chen et al., 2004). Entretanto, o estudo dos osteócitos ainda representa um desafio. Com esse objetivo, dentre os modelos descritos na literatura, destaca-se a utilização das Tiazolidinedionas (TZDs). As TZDs são uma classe de drogas utilizadas para o tratamento da diabetes melitus tipo 2 que desencadeiam efeitos colaterais no tecido ósseo (Sorocéanu et al., 2004; Ali et al., 2005; Di Paola et al., 2006; Hassumi et al., 2009; Mabilleau et al., 2010; Mieczkowska et al., 2011). Nesta classe de drogas, destaca-se a Rosiglitazona, a qual é um agonista sintético com alta afinidade pelo PPAR-y (peroxisome proliferator-activated receptor- $\gamma$ ). Esse receptor está envolvido na diferenciação de células progenitoras em osteoblastos ou adipócitos, e posteriormente relacionados com a diferenciação de osteócitos. Sabe-se que após o uso sistêmico e contínuo dessa droga, ocorre o aumento da apoptose de osteócitos (Wan et al., 2007; Mabilleau et al., 2010; Mieczkowska et al., 2012; Peer e Khamaisi, 2015).

O cementoblasto é um tipo celular localizado na superfície do cemento que cobre a raiz dentária, onde as fibras colágenas periodontais estão inseridas. São células que protegem a raiz do turnover ósseo e de reabsorções fisiológicas, uma vez que não apresentam receptores específicos para este fenômeno (Cho et al., 1991). No terço médio e apical, à medida que se formam novas camadas de cemento, alguns cementoblastos são incluídos na matriz cementária e denominados de cementócitos, se comportando fenotipicamente como os osteócitos. 
Um recente trabalho do nosso grupo de pesquisa demonstrou que, à semelhança dos osteócitos, os cementócitos expressam RANKL em resposta à infecção endodôntica (De Rossi et al., 2016). Entretanto, até o presente momento, não há estudos demonstrando a apoptose de cementócitos.

Assim, o objetivo desse estudo foi demonstrar a ocorrência de apoptose em cementócitos de camundongos que receberam sistemicamente a Rosiglitazona.

\section{MATERIAL E MÉTODOS}

Todos os procedimentos realizados nos animais foram conduzidos de acordo com as diretrizes éticas da Comissão de Ética no Uso de Animais da Universidade de São Paulo Campus de Ribeirão Preto (Processo 2014.1.450.58.8) e baseados no guia ARRIVE para o relato de estudos em animais (Kilkenny et al., 2010). Camundongos machos wild type da linhagem C57BL/6, com 4 a 6 semanas de idade e peso médio de 20 gramas foram utilizados $(n=12)$. Os animais foram adquiridos do Biotério Central da Universidade de São Paulo (USP) - Campus de Ribeirão Preto, São Paulo, Brasil, e mantidos no biotério da Faculdade de Odontologia de Ribeirão Preto - USP sob um ciclo de $12 \mathrm{~h}$ claro/escuro, temperatura e umidade controladas e com livre acesso à ração e água.

Para a indução da apoptose foi realizada administração sistêmica oral de Rosiglitazona (Sigma-Aldrich Ltda, São Paulo, Brasil) na dose de $10 \mathrm{mg} / \mathrm{kg}$, via oral (gavagem, 1 dose por dia), baseado em estudos prévios (Sorocéanu et al., 2004; Ali et al., 2005; Di Paola et al., 2006; Hassumi et al., 2009).

Assim, os animais foram randomizados de forma simples (usando uma tabela de números aleatórios) e divididos em dois grupos: G1 (controle), o qual recebeu apenas a administração via oral do veículo diariamente, por uma semana (PBS + DMSO 10\%) e G2 (experimental), o qual recebeu $10 \mathrm{mg} / \mathrm{kg}$ de Rosiglitazona + PBS + DMSO 10\% via oral (gavagem), diariamente, durante 2 semanas.

\section{PROCESSAMENTO HISTOTÉCNICO}

Após a conclusão dos períodos experimentais, os camundongos foram eutanasiados por injeção intramuscular de Ketamina $(150 \mathrm{mg} / \mathrm{kg})$ e Xilazina $(7.5 \mathrm{mg} / \mathrm{kg})$ e inalação de $\mathrm{CO}_{2}$ em câmara específica. As mandíbulas foram dissecadas e fixadas em formol tamponado a $10 \%$ durante 16 horas à temperatura ambiente, lavadas em água corrente durante 4 horas e descalcificadas em solução à base de ácido etilenodiaminotetraacético a 4,13\% (EDTA, pH 7,2). As peças foram mantidas nesta solução, à temperatura ambiente, trocada 
semanalmente, até sua completa descalcificação, o que ocorreu em aproximadamente 3 semanas. O grau de descalcificação das estruturas mineralizadas foi testado por meio da penetração de uma agulha nos tecidos, para verificação da sua consistência. Posteriormente, os espécimes foram submetidos a processamento histotécnico de rotina. As peças foram lavadas em água corrente por 2 horas, desidratadas em álcool de concentrações crescentes (70\% e 95\% por 30 minutos cada; 2 trocas de $100 \%$ por 20 minutos cada e 2 trocas de álcool $100 \%$ por 40 minutos cada), diafanizadas em xilol (2 banhos de 20 minutos e 1 de 40 minutos) e incluídas em parafina. Os blocos contendo as mandíbulas foram cortados longitudinalmente em micrótomo (Leica RM2145; Leica Microsystems GmbH, Wetzlar, Alemanha) no sentido mésio-distal. Cortes semi-seriados de $5 \mu \mathrm{m}$ foram obtidos incluindo os primeiros e segundos molares e o tecido ósseo alveolar. Por amostra, foram obtidas de 10 a 15 lâminas, com 3 cortes em cada lâmina (Silva et al., 2012; Oliveira et al., 2015).

\section{TESTE DE TUNEL}

A técnica de TUNEL (Terminal Deoxynucleotidyl Transferase-mediated Deoxyuridine Triphosphate (dUTP) Nick-end Labeling) foi realizada com a utilização de um kit para detecção de fragmentos de DNA derivado de células em apoptose (Apop Tag-Plus Kit Oncor Inc., Gaithersburg, Maryland, EUA) de acordo com o protocolo do fabricante. Os cortes foram pré-tratados em $20 \mu \mathrm{g} / \mathrm{ml}$ de proteinase $\mathrm{K}$ (Oncor-Protein Digesting Enzyme) durante 15 minutos a $37^{\circ} \mathrm{C}$ e, após várias lavagens em água destilada, foram imersos em peróxido de hidrogênio a 3\% em PBS (fosfato de sódio a $50 \mathrm{mM}, \mathrm{pH} 7,4, \mathrm{NaCl}$ a $200 \mathrm{mM}$ ) durante 15 minutos, e em seguida imersos em tampão de equilíbrio. Após incubação em enzima TdT (desoxinucleotidil transferase terminal) a $37^{\circ} \mathrm{C}$ durante 1 hora em câmara humidificada, a reação foi interrompida por imersão em tampão de parada/lavagem a $37^{\circ} \mathrm{C}$ durante 15 minutos. Em seguida, os cortes foram lavados em PBS durante 10 min e incubados em anti-digoxigenina-peroxidase a $37^{\circ} \mathrm{C}$ durante 1 hora, em câmara humidificada. Após lavagem em PBS, os cortes foram tratados com solução de 0,06\% de tetracloridrato de 3,38-diaminobenzidina (Sigma, St. Louis, Missouri, EUA) na presença de peróxido de hidrogênio a $0,1 \%$ durante 5 a 10 minutos, à temperatura ambiente. Os cortes foram contracorados com hematoxilina. Para controles positivos foram utilizados cortes de glândulas mamárias provenientes do kit. Os controles negativos foram obtidos por omissão da enzima TdT (Cerri et al., 2000). 


\section{COLORAÇÃO DE DAPI}

A coloração 4'-6-diamidino-2-fenilindol foi utilizada para analisar a condensação de DNA nas células em apoptose. Os cortes desparafinados foram lavados três vezes com PBS por cinco minutos cada, impermeabilizados com PBS-Triton a 0,5\% e lavados novamente três vezes com PBS por cinco minutos cada. Em seguida, foram incubados com 0,25 $\mathrm{g} / \mathrm{ml}$ do corante DAPI em PB (tampão fosfato) durante aproximadamente cinco minutos, à temperatura ambiente, em ambiente escuro.

\section{QuANTIFICAÇÃo de CEMENTócitos APOPtóticos}

Todas as análises foram realizadas em microscópio óptico convencional (Carl Zeiss MicroImaging $\mathrm{GmbH}$, Göttingen, Alemanha). Os dados foram lidos por um examinador experiente, cegos para os grupos. Nenhum filtro foi utilizado para a análise de TUNEL, enquanto que um filtro azul de microscópio apropriado foi utilizado para a visualização correta das lâminas coradas com DAPI (DAPI, Carl Zeiss MicroImaging GmbH, Göttingen, Alemanha). O cemento celular (terço apical) das raízes mesial e distal do primeiro e segundo molares inferiores de cada animal foi analisado. Foram analisados de cinco a seis campos microscópicos aleatórios para contagem de células (ampliação de 630x) para cada animal. A razão de cementócitos apoptóticos/cementócitos totais em cada campo foi calculada, utilizando-se o software Image $\mathrm{J}$ (1,49u National Institutes of Health, EUA). Foi calculada a média das razões de dois cortes para cada animal, e os valores de todos os animais por grupo em cada ponto de tempo foram considerados para análise estatística (Moin et al., 2014).

Os cementócitos TUNEL-positivos foram considerados quando corados com cor castanha, apresentando fragmentação de núcleo (Gavrieli et al., 1992). Os cementócitos DAPI-positivos foram considerados quando seus núcleos apresentavam manchas fluorescentes definidas, mostrando a condensação de DNA no núcleo (Chu et al., 2014; Chiu et al., 2015).

\section{ANÁLISE ESTATÍSTICA}

A análise estatística foi realizada utilizando-se o software Graph Pad Prism 4 (Graph Pad Software Inc., San Diego, EUA). Foi estabelecido um nível de significância de 5\% para todas as análises. Uma vez que os dados apresentaram distribuição normal (comprovado pelo teste de Shapiro-Wilk), o teste one-way ANOVA e o pós-teste de Tukey foram utilizados para comparação das diferenças entre médias de razão de contagem de células. 


\section{RESULTADOS}

O grupo controle mostrou significativamente menor proporção de cementócitos apoptóticos/cementócitos totais quando comparado ao grupo experimental $(p<0,05)$, independentemente da técnica avaliada (TUNEL ou DAPI) ( $p>0,05)$.

Os cortes corados pelo método TUNEL mostraram aproximadamente $20 \%(0,201 \pm$ $0,03)$ de cementócitos TUNEL-positivos no grupo controle e $26 \%(0,265 \pm 0,05)$ de cementócitos TUNEL-positivos no grupo que recebeu duas semanas de administração da Rosiglitazona ( $p=0,01)$ (Figuras $1 \mathrm{~A}$ e 1B).

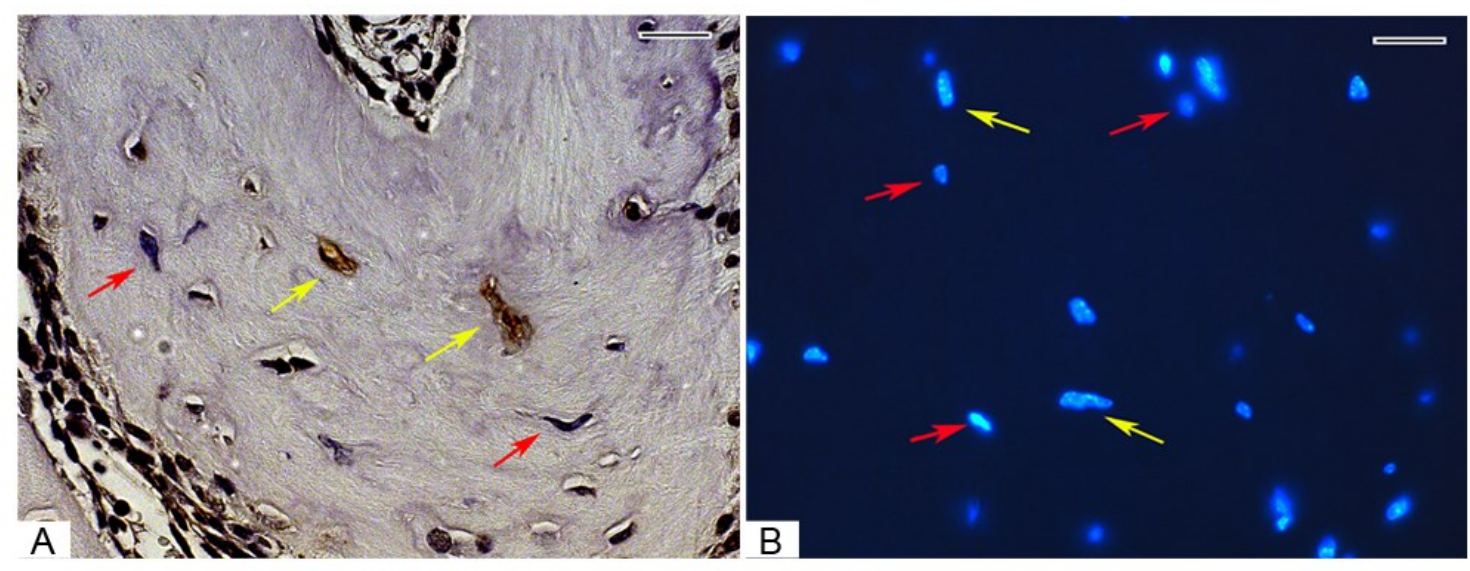

Figura 1: A) Imagem representativa do G2 (que recebeu a Rosiglitazona durante 2 semanas). As setas vermelhas mostram cementócitos não apoptóticos, com núcleos hígidos e coloração azul. As setas amarelas mostram cementócitos apoptóticas, com coloração castanha, vistas pela análise de TUNEL. B) Imagem representativa do G2 (que recebeu a Rosiglitazona durante 2 semanas). As setas vermelhas mostram células não apoptóticas, com núcleos hígidos (homogeneamente fluorescentes ou sem fluorescência). As setas amarelas mostram áreas de DNA condensadas nos núcleos celulares, vistas por pontos fluorescentes definidos, em células apoptóticas, por coloração com DAPI. Barra no canto superior direito das figuras $=20 \mu \mathrm{m}$.

Já a avaliação pela técnica DAPI mostrou aproximadamente $32 \%(0,327 \pm 0,06)$ de cementócitos DAPI-positivos no grupo controle e $40 \%(0,407 \pm 0,03)$ de cementócitos DAPIpositivos no grupo que recebeu a Rosiglitazona por duas semanas ( $p=0,004$ ) (Figuras $2 \mathrm{~A}$ e 2B). 

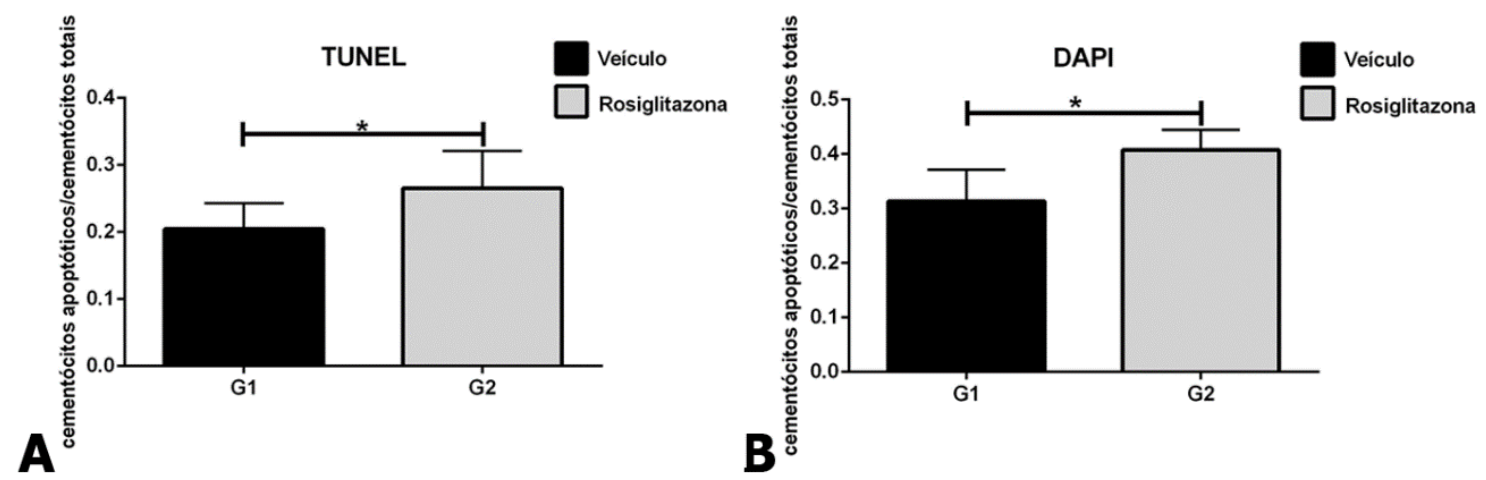

Figura 2: Relação de cementócitos apoptóticos/cementócitos totais nos grupos controle e duas semanas de administração de Rosiglitazona, respectivamente, medida pela técnica TUNEL (A) e DAPI (B).

\section{DISCUSSÃO}

Sabe-se que os adipócitos e osteócitos são originados da mesma célula progenitora, mudando seus destinos dependendo da ativação que esta recebe. Se ativada por RUNX2, a célula progenitora segue uma diferenciação para a linhagem osteoblastos, enquanto a ativação por PPAR-y leva ao desenvolvimento de adipócitos (Wiren, 2011). Como os TZDs são agonistas de PPAR-y, tem sido sugerido que estas drogas aumentam a diferenciação de adipócitos à custa de osteoblastos in vitro (Lecka-Czernik et al., 2002). Além disso, os TZDs foram relacionados com o aumento significativo da apoptose de osteócitos e expressão de esclerostina (Soroceanu et al., 2004; Mabilleau et al., 2010).

Assim, no presente estudo, ao corar as mandíbulas de camundongos que receberam a Rosiglitazona foi possível observar que os cementócitos apresentaram apoptose. Este evento nunca tinha sido previamente descrito e é aqui relatado para apresentar esta descoberta a outros investigadores e promover uma discussão sobre a função destas células na fisiologia e patologia dos tecidos periodontal e ósseo.

Além disso, foi observado que todos os animais do grupo controle também apresentaram cementócitos apoptóticos, evidenciando a normalidade deste evento. Entretanto, no grupo experimental, a Rosiglitazona aumentou significativamente a quantidade de cementócitos apoptóticos, conforme avaliado pelas técnicas TUNEL e DAPI (Figura 2).

No tecido ósseo, a apoptose é um fenômeno essencial, uma vez que desempenha papéis variados na ossificação endocondral, levando à mineralização da cartilagem, até a 
maturação óssea, responsável pela liberação de fatores angiogênicos que estimulam a invasão vascular e a migração de osteoblastos e osteoclastos, resultando na remodelação de cartilagem calcificada e formação de osso trabecular (Bassett e Williams, 2016).

Mediadores liberados pelo sistema lacuno-canalicular regulam a função dos osteoblastos e osteoclastos nas superfícies interna e externa das estruturas. Além disso, a rede tridimensional mecanosensorial de osteócitos controla a forma e o volume ósseos. Este fenômeno de formação/reabsorção representa o núcleo do controle fisiológico e metabólico do osso e do equilíbrio iônico no corpo (Dallas et al., 2013).

Nossa hipótese seria que os cementócitos, por meio da rede tridimensional determinada por seu Sistema lacuna-canalicular, poderiam ter participação no controle da posição e adaptação das estruturas radiculares na presença de vários fatores funcionais epigenéticos aos quais os dentes são submetidos, como carga oclusal, movimento ortodôntico, entre outros.

Apesar da diferença significativa entre os grupos controle e experimental, este é o primeiro estudo a demonstrar que os cementócitos sofrem apoptose, devido à administração de um TZD e também como fenômeno fisiológico. Este fato pode ajudar a esclarecer outras relações entre este tipo celular e outros no mesmo tecido, tecidos vizinhos ou distantes que ainda permanecem desconhecidos, além de evidenciar a necessidade de estudos futuros de forma a contribuir para o maior conhecimento sobre este tipo celular.

\section{CONCLUSÃO}

No presente estudo, pôde-se demonstrar pela primeira vez a ocorrência de apoptose em cementócitos de molares inferiores de camundongos wild type, e que este fenômeno foi estimulado pela administração sistêmica de Rosiglitazona por via oral durante 2 semanas, significantemente maior no grupo que recebeu o TZD.

\section{AGRADECIMENTOS}

Este estudo recebeu apoio financeiro do Conselho Nacional de Desenvolvimento Científico e Tecnológico (CNPq) [projeto n 444604/2014-6]. (Anexo B) 



\section{Conclusão}



O presente estudo caracterizou-se pela avaliação do efeito da administração de uma Tiazolinedinediona (Rosiglitazona) em camundongos por via oral (gavagem), na dose de $10 \mathrm{mg} / \mathrm{kg}$ como protocolo para estimular a apoptose de osteócitos em maxilares.

Foi possível observar que lesões periapicais induzidas em camundongos que receberam a administração da Rosiglitazona por duas semanas apresentaram tendência de aumento em comparação com camundongos dos grupos controle, além de maior número de osteoclastos, maior expressão do Sost (esclerostina) e do Hyou1 (ORP150) e ausência de alteração na expressão de $D m p 1$ e da densidade mineral óssea em fêmures.

Além disso, foi possível observar que essa classe de medicamentos induziu a apoptose de cementócitos, fato nunca antes descrito, visto que este tipo celular constitui um dos menos estudados e compreendidos fisiologicamente e patologicamente, na cavidade bucal.

Assim, após as metodologias empregadas e os parâmetros analisados neste estudo, pôde-se concluir que o uso sistêmico da Rosiglitazona estimulou a apoptose de osteócitos e cementócitos interferindo na formação e progressão de lesões periapicais em camundongos.

Destaca-se que estudos adicionais são necessários a fim de elucidar os mecanismos moleculares de compensação/estimulação da resposta do hospedeiro envolvidos no contexto de formação e progressão das lesões periapicais. 

Referêncías 

Al-Dujaili SA, Lau E, Al-Dujaili H, Tsang K, Guenther A, You L. Apoptotic osteocytes regulate osteoclast precursor recruitment and differentiation in vitro. J Cell Biochem. 2011;112:24122423.

Aleshin AN, Sawa Y, Kitagawa-Sakakida S, Bando Y, Ono M, Memon IA, Tohyama M, Ogawa $\mathrm{S}$, Matsuda H. 150-kDa oxygen-regulated protein attenuates myocardial ischemia-reperfusion injury in rat heart. J Mol Cell Cardiol. 2005 Mar;38(3):517-25.

Ali AA, Weinstein RS, Stewart SA, Parfitt AM, Manolagas SC, Jilka RL. Rosiglitazone causes bone loss in mice by suppressing osteoblast differentiation and bone formation. Endocrinology. 2005 Mar;146(3):1226-35.

Assed S, Ito IY, Leonardo MR, Silva LA, Lopatin DE. Anaerobic microorganisms in root canals of human teeth with chronic apical periodontitis detected by indirect immunofluorescence. Endod Dent Traumatol. 1996 Apr;12(2):66-9.

Atkins GJ, Findlay DM. Osteocyte regulation of bone mineral: a little give and take. Osteoporos Int. 2012;23:2067-2079.

Atkins GJ, Rowe PS, Lim HP, Welldon KJ, Ormsby R, Wijenayaka AR, Zelenchuk L, Evdokiou A, Findlay DM. Sclerostin is a locally acting regulator of late-osteoblast/preosteocyte differentiation and regulates mineralization through a MEPE-ASARM-dependent mechanism. J Bone Miner Res. 2011 Jul;26(7):1425-36.

Bassett JHD, Williams GR. Role of Thyroid Hormones in Skeletal Development and Bone Maintenance. Endocr Rev. 2016 Apr;37(2):135-187.

Bellido T, Ali AA, Gubrij I, Plotkin LI, Fu Q, O'Brien CA et al. Chronic elevation of parathyroid hormone in mice reduces expression of sclerostin by osteocytes: A novel mechanism for hormonal control of osteoblastogenesis. Endocrinology. 2005;146:4577-4583.

Bellido T. Osteocyte-driven bone remodeling. Calcif Tissue Int. 2014 Jan;94(1):25-34.

Beno T, Yoon YJ, Cowin SC, Fritton SP. Estimation of bone permeability using accurate microstructural measurements. J Biomech. 2006;39(13):2378- 2387.

Bielaczyc A, Gołebiewska M. Ultrastructural changes of a tooth root in young rats fed a low calcium and vitamin D-deficient diet. Rocz Akad Med Bialymst. 1997;42(Suppl 2):153-158.

Bivi N, Condon KW, Allen MR, et al. Cell autonomous requirement of connexin 43 for osteocyte survival: consequences for endocortical resorption and periosteal bone formation. J Bone Miner Res. 2012a;27:374-89.

Bivi N, Nelson MT, Faillace ME, Li J, Miller LM, Plotkin LI. Deletion of Cx43 from osteocytes results in defective bone material properties but does not decrease extrinsic strength in cortical bone. Calcif Tissue Int. 2012b;91(3):215-24.

Bonewald LF. Osteocytes as dynamic multifunctional cells. Ann New York Acad Sci. 2007;1116:281-290.

Bonewald LF. The amazing osteocyte. J Bone Miner Res. 2011;26:229-238. 
Bosshardt DD. Are cementoblasts a subpopulation of osteoblasts or a unique phenotype? J Dent Res. 2005;84(5):390-406.

Broulík PD, Sefc L, Haluzík M. Effect of PPAR-y agonist rosiglitazone on bone mineral density and serum adipokines in C57BL/6 male mice. Folia Biol (Praha). 2011;57(4):133-8.

Butler WT, Ritchie HH, Bronckers AL. Extracellular matrix proteins of dentine. Ciba Foundation Symposium. 1997;205:107-15;115-117.

Camilleri S, McDonald F. RUNX2 and dental development. Eur J Oral Sci. 2006;114(5):361373.

Candeliere GA, Liu F, Aubin JE. Individual osteoblasts in the developing calvaria express different gene repertoires. Bone. 2001;28:351-61.

Cao Z, Zhang H, Zhou X, Han X, Ren Y, Gao T, Xiao Y, de Crombrugghe B, Somerman MJ, Feng JQ. Genetic evidence for the vital function of osterix in cementogenesis. J Bone Miner Res. 2012;27(5):1080-1092.

Cerri PS, Freymuller, E., \& Katchburian, E. Apoptosis in the early developing periodontium of rat molars. Anat Rec. 2000;258(2), 136-144.

Chen J, Shapiro HS, Sodek J. Development expression of bone sialoprotein mRNA in rat mineralized connective tissues. J Bone Miner Res. 1992;7:987-997.

Chen $\mathrm{H}$, Shoumura $\mathrm{S}$, Emura $\mathrm{S}$. Ultrastructural changes in bones of the senescenceaccelerated mouse (SAMP6): a murine model for senile osteoporosis. Histol Histopathol. 2004;19:677-685.

Cherian PP, Siller-Jackson AJ, Gu S, Wang X, Bonewald LF, Sprague E, et al. Mechanical strain opens connexin 43 hemichannels in osteocytes: A novel mechanism for the release of prostaglandin. Mol Biol Cell. 2005;16:3100-3106.

Chiu CH, Chou YC, Lin JP, Kuo CL, Lu HF, Huang YP et al. Chloroform Extract of Solanum lyratum Induced G0/G1 Arrest via p21/p16 and Induced Apoptosis via Reactive Oxygen Species, Caspases and Mitochondrial Pathways in Human Oral Cancer Cell Lines. Am J Chin Med. 2015;43(7):1453-1469.

Cho MI, Lin, WL, \& Garant PR. Occurrence of epidermal growth factor-binding sites during differentiation of cementoblasts and periodontal ligament fibroblasts of the young rat: a light and electron microscopic radioautographic study. Anat Rec. 1991;231(1):14-24.

Chu F, Xu X, Li G, Gu S, Xu K, Gong Y et al. Amino acid derivatives of ligustrazine-oleanolic acid as new cytotoxic agents. Molecules. 2014;19(11):18215-18231.

Dallas SL, Prideaux M, Bonewald F. The osteocyte: an endocrine cell and more. Endocrine Reviews. 2013;10:2012-1026.

Dallas SL, Veno PA, Rosser JL, Barragan-Adjemian C, Rowe DW, Kalajzic I, Bonewald LF. Time lapse imaging techniques for comparison of mineralization dynamics in primary murine osteoblasts and the late osteoblast/early osteocyte-like cell line MLO-A5. Cells Tissues Organs. 2009;189(1-4):6-11. 
De Oliveira KM, da Silva RA, De Rossi A, Fukada SY, Feres M, Nelson-Filho P, da Silva LA. Absence of interleukin 22 affects the oral microbiota and the progression of induced periapical lesions in murine teeth. Int Endod J. 2015 Jan;48(1):46-59.

De Rossi A, De Rossi M, Rocha LB, da Silva LA, Rossi MA. Morphometric analysis ofexperimentally induced periapical lesions: radiographic vs histopathological findings. Dentomaxillofac Radiol. 2007;36:211-217.

De Rossi A, Fukada SY, De Rossi M, da Silva RA, Queiroz AM, Nelson-Filho P, da Silva LA. Cementocytes Express Receptor Activator of the Nuclear Factor Kappa-B Ligand in Response to Endodontic Infection in Mice. J Endod. 2016 Aug;42(8):1251-7.

De Rossi A, Rocha LB, Rossi MA. Interferon-gamma, interleukin-10, intercellular adhesion molecule-1, and chemokine receptor 5, but not interleukin-4, attenuate the development of periapical lesions. J Endod. 2008;34:31-38.

Di Paola R, Mazzon E, Maiere D, Zito D, Britti D, De Majo M, Genovese T, Cuzzocrea S. Rosiglitazone Reduces the Evolution of Experimental Periodontitis in the Rat. J Dent Res. 2006;85:156-161.

Dormandy JA, Charbonnel B, Eckland DJ, Erdmann E, Massi-Benedetti M, Moules IK, et al. Secondary prevention of macrovascular events in patients with type 2 diabetes in the Proactive Study (Prospective pioglitazone Clinical Trial In macrovascular Events): a randomized controlled trial. Lancet. 2005;366:1279-1289.

Eapen A, Sundivakkam P, Song Y, Ravindran S, Ramachandran A, Tiruppathi C, George A. Calcium-mediated stress kinase activation by DMP1 promotes osteoblast differentiation. J Biol Chem. 2010;285:36339-36351.

Fabricius L, Dahlén G, Ohman AE, Möller AJ. Predominant indigenous oral bacteria isolated from infected root canals after varied times of closure. Scand J Dent Res. 1982 Apr;90(2):134-44.

Feng JQ, Huang H, Lu Y, Ye L, Xie Y, Tsutsui TW, Kunieda T, Castranio T, Scott G, Bonewald LB, Mishina Y. The Dentin matrix protein 1 (Dmp1) is specifically expressed in mineralized, but not soft, tissues during development. J Dent Res. 2003;82:776-780

Feng JQ, Ward LM, Liu S, Lu Y, Xie Y, Yuan B, et al. Loss of DMP1 causes rickets and osteomalacia and identifies a role for osteocytes in mineral metabolism. Nat Genet. 2006;38:1310-1315.

Foster BL. Methods for studying tooth root cementum by light microscopy. Int J Oral Sci. 2012;4(3):119-128.

Foster BL, Somerman MJ. Cementum. In: McCauley LK, Somerman MJ, editors. Mineralized tissues in oral and craniofacial science: biological principles and clinical correlates. Ames, IA: Wiley-Blackwell. 2012;169-192.

Franz-Odendaal TA, Hall BK, Witten PE. Buried Alive: How Osteoblasts Become Osteocytes. Dev Dyn. 2006;235:176-190.

Garlet TP, Fukada SY, Saconato IF et al. CCR2 deficiency results in increased osteolysis in experimental periapical lesions in mice. J Endod. 2010;36:244-50. 
Gavrieli Y, Sherman Y, Ben-Sasson SA. Identification of programmed cell death in situ via specific labeling of nuclear DNA fragmentation. J Cell Biol. 1992;119(3):493-501.

George A, Sabsay B, Simonian PA, Veis A. Characterization of a novel dentin matrix acidic phosphoprotein. Implications for induction of biomineralization. J Biol Chem. 1993;268:12624-12630.

Goodenough DA, Goliger JA, Paul DL. Connexins, connexons, and intercellular communication. Annu Rev Biochem. 1996;65:475-502.

Graves DT, Oates T, Garlet GP. Review of osteoimmunology and the host response in endodontic and periodontal lesions. J Oral Microbiol. 2011;3:5304.

Gu G, Nars M, Hentunen TA, Metsikkö K, Väänänen HK. Isolated primary osteocytes express functional gap junctions in vitro. Cell Tissue Res. 2006;323:263-71.

Halleux C, Kramer I, Allard C, Kneissel M. Isolation of mouse osteocytes using cell fractionation for gene expression analysis. Methods Mol Biol. 2012;816:55-66.

Harris SE, Gluhak-Heinrich J, Harris MA, Yang W, Bonewald LF, Riha D, et al. DMP1 and MEPE expression are elevated in osteocytes after mechanical loading in vivo: theoretical role in controlling mineral quality in the perilacunar matrix. J Musculoskelet Neuronal Interact. 2007;7:313-315.

Hassumi MY, Silva-Filho VJ, Campos-Júnior JC, Vieira SM, Cunha FQ, Alves PM, et al. PPAR-Y agonist rosiglitazone prevents inflammatory periodontal bone loss by inhibiting osteoclastogenesis. Int Immunopharmacol. 2009;9:1150-1158.

Huang B, Maciejewska I, Sun Y, Peng T, Qin D, Lu Y, et al. Identification of full-length dentin matrix protein 1 in dentin and bone. Calcif Tissue Int. 2008;82:401-410.

Jäger A, Götz W, Lossdörfer S, Rath-Deschner B. Localization of SOST/sclerostin in cementocytes in vivo and in mineralizing periodontal ligament cells in vitro. J Periodontal Res. 2010;45(2):246-54.

Jiang B, Cao Z, Lu Y, Janik C, Lauziere S, Xie Y, et al. DMP1 C-terminal mutant mice recapture the human ARHR tooth phenotype. J Bone Miner Res. 2010;25:2155-2164.

Jilka RL, Noble B, Weinstein RS. Osteocyte apoptosis. Bone. 2013;54(2):264-71.

Kagayama M, Sasano Y, Mizoguchi I, Takahashi I. Confocal microscopy of cementocytes and their lacunae and canaliculi in rat molars. Anat Embryol (Berl). 1997;195(6):491-496.

Kahn SE, Haffner SM, Heise MA, Herman WH, Holman RR, Jones NP, et al. Glycemic durability of rosiglitazone, metformin, or glyburide monotherapy. $\mathrm{N}$ Engl J Med. 2006;355:2427-2443.

Kalajzic I, Matthews BG, Torreggiani E, Harris MA, Divieti Pajevic P, Harris SE. In vitro and in vivo approaches to study osteocyte biology. Bone. 2013 Jun;54(2):296-306.

Kawashima N, Stashenko P. Expression of bone-resorptive and regulatory cytokines in murine periapical inflammation. Arch Oral Biol. 1999;44:55-66. 
Kawashima N, Suzuki N, Yang G, Ohi C, Okuhara S, Nakano-Kawanishi H, Suda H. Kinetics of RANKL, RANK and OPG expressions in experimentally induced rat periapical lesions. Oral Surg Oral Med Oral Pathol Oral Radiol Endod. 2007 May;103(5):707-11.

Kawashima Y, Fritton JC, Yakar S, Epstein S, Schaffler MB, Jepsen KJ, LeRoith D. Type 2 diabetic mice demonstrate slender long bones with increased fragility secondary to increased osteoclastogenesis. Bone. 2009 Apr;44(4):648-55.

Kamiya N, Takagi M. Differential expression of dentin matrix protein 1, type I collagen and osteocalcin genes in rat developing mandibular bone. Histochem J. 2001;33:545-52.

Kato Y, Windle JJ, Koop BA, Mundy GR, Bonewald LF. Establishment of an osteocyte-like cell line, MLO-Y4. J Bone Miner Res. 1997 Dec;12(12):2014-23.

Kilkenny C, Browne W, Cuthill IC, Emerson M, Altman DG; NC3Rs Reporting Guidelines Working Group.. Animal research: reporting in vivo experiments: the ARRIVE guidelines. $\mathrm{Br}$ J Pharmacol. 2010 Aug;160(7):1577-9.

Klein-Nulend J, Sterck J, Semeins C, Lips P, Joldersma M, Baart J, et al. Donor age and mechanosensitivity of human bone cells. Osteoporos Int. 2002;13:137-146.

Kogianni G, Mann V, Noble BS. Apoptotic bodies convey activity capable of initiating osteoclastogenesis and localized bone destruction. J Bone Miner Res. 2008;23:915-27.

Komori T. Mouse models for the evaluation of osteocyte functions. J Bone Metab. 2014;21(1):55-60.

Kular J, Tickner J, Chim SM, Xu J. An overview of the regulation of bone remodelling at the cellular level. Clin Biochem. 2012;45:863-873.

Kulkarni GV, Chen B, Malone JP, Narayanan AS, George A. Promotion of selective cell attachment by the RGD sequence in dentine matrix protein 1. Arch Oral Biol. 2000;45:475484.

Lecka-Czernik B, Gubrij I, Moerman EJ, Kajkenova O, Lipschitz DA, Manolagas SC, et al. Inhibition of Osf2/Cbfa1 expression and terminal osteoblast differentiation by PPARy2. J Cell Biochem. 1999;74:357-371.

Lecka-Czernik B, Moerman EJ, Grant DF, Lehmann JM, Manolagas SC, Jilka RL. Divergent effects of selective peroxisome proliferator-activated receptor-_2 ligands on adipocyte versus osteoblast differentiation. Endocrinology. 2002;143:2376-2384.

Lehnen SD, Götz W, Baxmann M, Jäger A. Immunohistochemical evidence for sclerostin during cementogenesis in mice. Ann Anat. 2012;194(5):415-421.

Li X, Chen W, Zeng W, Wan C, Duan S, Jiang S. microRNA-137 promotes apoptosis in ovarian cancer cells via the regulation of XIAP. Br ] Cancer. 2016 Nov 22.[Epub ahead of print] PubMed PMID: 27875524.

Li X, Ominsky MS, Niu QT, et al. Targeted deletion of the sclerostin gene in mice results in increased bone formation and bone strength. J Bone Miner Res. 2008;23:860-869. 
Li X, Zhang Y, Kang H, Liu W, Liu P, Zhang J, et al. Sclerostin binds to LRP5/6 and antagonizes canonical Wnt signaling. J Biol Chem. 2005;280:19883-19887.

Liu F, Malaval L, Aubin JE. The mature osteoblast phenotype is characterized by extensive plasticity. Exp Cell Res. 1997;232:97-105.

Loiselle $\mathrm{AE}$, Jiang JX, Donahue $\mathrm{HJ}$. Gap junction and hemichannel functions in osteocytes. Bone. 2013;54(2):205-12.

Lorenz-Depiereux B, Bastepe $M$, Benet-Pagès $A$, Amyere $M$, Wagenstaller J, Müller-Barth $U$, et al. DMP1 mutations in autosomal recessive hypophosphatemia implicate a bone matrix protein in the regulation of phosphate homeostasis. Nat Genet. 2006;38:1248-1250.

Lucisano MP, Nelson-Filho P, Morse L, Battaglino R, Watanabe PC, Silva RA, Silva LA. Radiodensitometric and DXA analyses for the measurement of bone mineral density after systemic alendronate therapy. Braz Oral Res. 2013 May-Jun;27(3):252-7.

Mabilleau G, Mieczkowska A, Edmonds ME. Original Article: Thiazolidinediones induce osteocyte apoptosis and increase sclerostin expression. Diabet Med. 2010;27:925-932.

MacDonald BT, Joiner DM, Oyserman SM, et al. Bone mass is inversely proportional to Dkk1 levels in mice. Bone. 2007;41:331-339.

Maciejewska I, Qin D, Huang B, Sun Y, Mues G, Svoboda K, et al. Distinct compartmentalization of dentin matrix protein 1 fragments in mineralized tissues and cells. Cells Tissues Organs. 2009;189:186-191.

Mark MP, ButlerWT, Prince CW, Finkelman RD, Ruch JV. Developmental expression of 44$\mathrm{kDa}$ bone phosphoprotein (osteopontin) and bone gamma-carboxyglutamic acid (Gla)containing protein (osteocalcin) in calcifying tissues of rat. Differentiation. 1988;37:123-136.

Menezes R, Garlet TP, Trombone AP, et al. The potential role of supressors of cytokine signaling in the attenuation of inflammatory reaction and alveolar bone loss associated with apical periodontitis. J Endod. 2008;34:1480-4.

Mieczkowska A, Baslé MF, Chappard D, Mabilleau G. Thiazolidinediones Induce Osteocyte Apoptosis by a G-Protein-coupled Receptor 40-dependent Mechanism. J Biol Chem. 2012;287:23517-23526.

Miyagi T, Hori O, Koshida K, Egawa M, Kato H, Kitagawa Y, Ozawa K, Ogawa S, Namiki M. Antitumor effect of reduction of $150-\mathrm{kDa}$ oxygen-regulated protein expression on human prostate cancer cells. Int J Urol. 2002 Oct;9(10):577-85.

Mohammadi Z. Endotoxin in endodontic infections: a review. J Calif Dent Assoc. 2011 Mar;39(3):152-5, 158-61.

Moin S, Kalajzic Z, Utreja A, Nihara J, Wadhwa S, Uribe F, Nanda R. Osteocyte death during orthodontic tooth movement in mice. Angle Orthod. 2014;84(6):1086-1092.

Montesi M, Jähn K, Bonewald L, Stea S, Bordini B, Beraudi A. Hypoxia mediates osteocyte ORP150 expression and cell death in vitro. Mol Med Rep. 2016 Nov;14(5):4248-4254. 
Moriishi T, Fukuyama R, Ito M, Miyazaki T, Maeno T, Kawai Y, et al. Osteocyte network; a negative regulatory system for bone mass augmented by the induction of Rankl in osteoblasts and Sost in osteocytes at unloading. PLoS One. 2012;7:40143.

Mulcahy LE, Taylor D, Lee TC, Duffy GP. RANKL and OPG activity is regulated by injury size in networks of osteocyte-like cells. Bone. 2011;48:182-188.

Narayanan K, Ramachandran A, Hao J, He G, Park KW, Cho M, et al. Dual functional roles of dentin matrix protein 1 . Implications in biomineralization and gene transcription by activation of intracellular Ca2+ store. J Biol Chem. 2003;278:17500-17508.

Neuhaus SJ, Byers MR. Endothelin receptors and endothelin-1 in developing rat teeth. Arch Oral Biol. 2007;52(7):655-662.

Neve A, Corrado A, Cantatore FP. Osteocytes: central conductors of bone biology in normal and pathological conditions. Acta Physiol. 2012;204:317-330.

O'Brien CA, Nakashima T, Takayanagi H. Osteocyte control of osteoclastogenesis. Bone. 2013;54(2):258-263.

Ominsky MS, Li C, Li X, Tan $\mathrm{HL}$, Lee $\mathrm{E}$, Barrero $\mathrm{M}$, et al. Inhibition of sclerostin by monoclonal antibody enhances bone healing and improves bone density and strength of nonfractured bones. J Bone Miner Res. 2011;26(5):1012-1021.

Poole KE, van Bezooijen RL, Loveridge N, Hamersma $H$, Papapoulos SE, Löwik CW, et al. Sclerostin is a delayed secreted product of osteocytes that inhibits bone formation. FASEB J. 2005; 19:1842-1844.

Peer A, Khamaisi M. Diabetes as a risk factor for medication-related osteonecrosis of the jaw. J Dent Res. 2015 Feb;94(2):252-60.

Pesce-Viglietti AI, Arriola Benitez PC, Gentilini MV, Velásquez LN, Fossati CA, Giambartolomei $\mathrm{GH}$, Delpino MV. Brucella abortus Invasion of Osteocytes Modulates Connexin 43 and Integrin Expression and Induces Osteoclastogenesis via Receptor Activator of NF-KB Ligand and Tumor Necrosis Factor Alpha Secretion. Infect Immun. 2015 Oct 12;84(1):11-20.

Plotkin LI. Apoptotic osteocytes and the control of targeted bone resorption. Curr Osteoporos Rep. 2014 Mar;12(1):121-6.

Plotkin LI, Gortazar AR, Davis HM, Condon KW, Gabilondo H, Maycas M, Allen MR, Bellido T. Inhibition of osteocyte apoptosis prevents the increase in osteocytic receptor activator of nuclear factor $\mathrm{KB}$ ligand (RANKL) but does not stop boné resorption or the loss of bone induced by unloading. J Biol Chem. 2015 Jul 31;290(31):18934-42.

Quarles LD. Evidence for a bone-kidney axis regulating phosphate homeostasis. J Clin Invest. 2003;112:642-646.

Robinson RA. Bone tissue: composition and function. Johns Hopkins Med J. 1979 Jul;145(1):10-24. 
Robling AG, Niziolek PJ, Baldridge LA, Condon KW, Allen MR, Alam I, et al. Mechanical stimulation of bone in vivo reduces osteocyte expression of Sost/sclerostin. J Biol Chem. 2008;283(9):5866-5875.

Rocha CT, Rossi MA, Leonardo MR, Rocha LB, Nelson-Filho P, Silva LA. Biofilm on the apical region of roots in primary teeth with vital and necrotic pulps with or without radiographically evident apical pathosis. Int Endod J. 2008 Aug;41(8):664-9.

Rochefort GY, Pallu S, Benhamou CL. Osteocyte: the unrecognized side of bone tissue. Osteoporos Int. 2010;21:1457-1469.

Salvador VAG. Avaliação de apoptose e necrose em Saccharomyces cerevisiae em fermentações vinárias. Lisboa. Dissertação [Mestrado em Engenharia Alimentar]. Instituto Superior de Agronomia da Universidade Técnica de Lisboa; 2009.

San Miguel SM, Fatahi MR, Li H, Igwe JC, Aguila HL, Kalajzic I. Defining a visual marker of osteoprogenitor cells within the periodontium. J Periodontal Res. 2010;45(1):60-70.

Sasaki H, Balto K, Kawashima N, Eastcott J, Hoshino K, Akira S, et al. Gamma interferon (IFN-gamma) and IFNgamma-inducing cytokines interleukin-12 (IL-12) and IL-18 do not augment infection-stimulated bone resorption in vivo. Clin Diagn Lab Immunol. 2004;11:106110.

Sato S, Hashimoto J, Usami Y, Ohyama K, Isogai Y, Hagiwara Y, et al. Novel sandwich ELISAs for rat DMP1: age-related decrease of circulatory DMP1 levels in male rats. Bone. 2013;57:429-36.

Scivetti M, Pilolli GP, Corsalini M, Lucchese A, Favia G. Confocal laser scanning microscopy of human cementocytes: analysis of three-dimensional image reconstruction. Ann Anat. 2007;189(2):169-174.

Semenov M, Tamai K, He X. SOST is a ligand for LRP5/LRP6 and a Wnt signaling inhibitor. J Biol Chem. 2005;280:26770-26775.

Schaffler MB, Kennedy OD. Osteocyte signaling in bone. Current Osteoporosis Reports. 2012;10:118-125.

Silva RAB, Ferreira PDF, De Rossi A, Nelson-Filho P, Silva LAB. Toll-like Receptor 2 Knockout Mice Showed Increased Periapical Lesion Size and Osteoclast Number. J Endod. 2012;38:803-813.

Sjögren U, Figdor D, Persson S, Sundqvist G. Influence of infection at the time of root filling on the outcome of endodontic treatment of teeth with apical periodontitis. Int Endod J. 1997 Sep;30(5):297-306.

Sorocéanu MA, Miao D, Bai X, Su H, Goltzmand D, Karaplis AC. Rosiglitazone impacts negatively on bone by promoting osteoblast/osteocyte apoptosis. J Endocrinol. 2004;183:203-216.

Staehling-Hampton K, Proll S, Paeper BW, et al. A 52-kb deletion in the SOST-MEOX1 intergenic region on 17q12-q21 is associated with van Buchem disease in the Dutch population. Am J Med Genet. 2002; 110:144-152. 
Stern AR, Bonewald LF. Isolation of osteocytes from mature and aged murine bone. Methods Mol Biol. 2015; 1226: 3-10.

Stern AR, Stern MM, Van Dyke ME, Jähn K, Prideaux M, Bonewald LF. Isolation and culture of primary osteocytes from the long bones of skeletally mature and aged mice. Biotechniques. 2012;52:361-373.

Stojadinovic A, Hooke JA, Shriver CD, Nissan A, Kovatich AJ, Kao TC, Ponniah S, Peoples GE, Moroni M. HYOU1/Orp150 expression in breast cancer. Med Sci Monit. 2007 Nov;13(11):BR231-239.

Szczęsny G, Brodzikowska A, Galus R, Włodarski P, Włodarski KH. Regulation of Bone Homeostasis by Osteocytes. Ortop Traumatol Rehabil. 2015 Nov-Dec;17(6):567-675.

Tate MLK, Adamson JR, Tami AE, Bauer TW. The osteocyte. Int J Biochem Cell Biol. 2004;36:1-8.

Tatsumi S, Ishii K, Amizuka N, Li M, Kobayashi T, Kohno K, et al. Targeted ablation of osteocytes induces osteoporosis with defective mechanotransduction. Cell Metabol. 2007; 5:464-475.

Tian X, Jee WS, Li X, Paszty C, Ke HZ. Sclerostin antibody increases bone mass by stimulating bone formation and inhibiting bone resorption in a hindlimb-immobilization rat model. Bone. 2011;48(2):197-201.

Tomkinson A, Reeve J, Shaw RW, Noble BS. The death of osteocytes via apoptosis accompanies estrogen withdrawal in human bone. J Clin Endocrinol Metab. 1997;82:31283135.

Toyosawa S, Shintani S, Fujiwara T, Ooshima T, Sato A, Ijuhin N, et al. Dentin matrix protein 1 is predominantly expressed in chicken and rat osteocytes but not in osteoblasts. J Bone Miner Res. 2001;16:2017-26.

Uzbekov R, Maurel D, Aveline P, Pallu S, Benhamou C, Rochefort G. Centrosome fine ultrastructure of the osteocyte mechanosensitive primary cilium. Microsc Microanal. 2012;18:1430-1441.

van Bezooijen RL, Bernard AJ, Roelen BAJ, Visser A, van der Wee-Pals $L$, de Wilt $E$, et al. Sclerostin Is an Osteocyte-expressed Negative Regulator of Bone Formation, But Not a Classical BMP Antagonist. J Exp Med. 2004;199:805-814.

Vandevska-Radunovic V, Fristad I, Wimalawansa SJ, Kvinnsland I. CGRP1 and NK1 receptors in postnatal, developing rat dental tissues. Eur J Oral Sci. 2003;111(6):497-502.

Wan Y, Chong LW, Evans RM. PPAR-gamma regulates osteoclastogenesis in mice. Nat Med. 2007;13:1496-503.

Weatherholt AM, Fuchs RK, Warden SJ. Specialized connective tissue: bone, the structural framework of the upper extremity. J Hand Ther. 2012;25(2):123-31.

Wei C, Fan B, Chen D, Liu C, Wei Y, Huo B, You L, Wang J, Chen J. Osteocyte culture in microfluidic devices. Biomicrofluidics. 2015 Jan 26;9(1):014109. 
Weinstein RS, Nicholas RW, Manolagas SC. Apoptosis of osteocytes in glucocorticoid-induced osteonecrosis of the hip. J Clin Endocrinol Metab. 2000;85:2907-2912

Wijenayaka AR, Kogawa M, Lim HP, et al. Sclerostin stimulates osteocyte support of osteoclast activity by a RANKL-dependent pathway. PloS one. 2011;6(10):e25900.

Winkler DG, Sutherland MK, Geoghegan JC, Yu C, Hayes T, Skonier JE, et al. Osteocyte control of bone formation via sclerostin, a novel BMP antagonist. EMBO J. 2003;22:62676276.

Wiren KM. Bone vs. fat: Embryonic origin of progenitors determines response to androgen in adipocytes and osteoblasts. 2011;49(4):662-672.

Wright HL, McCarthy HS, Middleton J, Marshall MJ. RANK, RANKL and osteoprotegerin in bone biology and disease. Curr Rev Musculoskelet Med. 2009;2:56-64.

Xu H, Gu S, Riquelme MA, Burra S, Callaway D, Cheng $H$, et al. Connexin 43 channels are essential for normal bone structure and osteocyte viability. J Bone Miner Res. 2015 Mar;30(3):436-48.

Wu H, Teng PN, Jayaraman T, Onishi S, Li J, Bannon L, et al. Dentin matrix protein 1 (DMP1) signals via cell surface integrin. J Biol Chem. 2011;286:29462-29469.

Xiong J, Onal M, Jilka RL, Weinstein RS, Manolagas SC, O'Brien CA. Matrix-embedded cells control osteoclast formation. Nat Med. 2011;17(10):1235-1241.

Xu H, Gu S, Riquelme MA, Burra S, Callaway D, Cheng H, et al. Connexin 43 channels are essential for normal bone structure and osteocyte viability. J Bone Miner Res. 2015 Mar;30(3):436-48.

Yasuda H, Shima N, Nakagawa N, Yamaguchi K, Kinosaki M, Mochizuki S, et al. Osteoclast differentiation factor is a ligand for osteoprotegerin/osteoclastogenesis-inhibitory factor and is identical to TRANCE/RANKL. Proc Natl Acad Sci USA. 1998 Mar 31;95(7):3597-602.

Zhao N, Nociti FH Jr, Duan P, Prideaux M, Zhao H, Foster BL, Somerman MJ, Bonewald LF. Isolation and functional analysis of an immortalized murine cementocyte cell line, IDG-CM6. J Bone Mineral Res. 2016;31(2):430-442. 
Anexos 



\section{ANEXo A}

\section{UNIVERSIDADE DE SÃO PAULO \\ FACULDADE DE ODONTOLOGIA DE RIBEIRİO PRETO \\ Comissão de Ética no Uso de Animais}

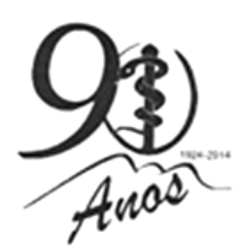

Of. CEUA 031/2014

Ribeirão Preto, 18 de junho de 2014.

Ref. processo $n^{\circ} 2014.1 .405 .58 .8$

Senhor(a) Pesquisador(a),

Informamos que a Comissão de Ética no Uso de Animais da FORP, em reunião realizada em 18 de junho de 2014, referendou a aprovação do projeto "Papel dos osté́citos na formação e progressão de lesões periapiacais em dentes de camundongos", emitindo o certificado anexo.

Informamos, também, que deverá ser entregue na Secretaria da CEUA, até o dia 01/07/2016, o Relatório Final contendo os resultados e/ou resumo do trabalho publicado.

Atenciosamente,

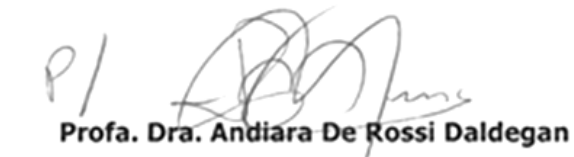

Coordenadora da Comissão de Ética no Uso de Animais

$\operatorname{IImo(a).~} \operatorname{Sr}(a)$.

Profa. Dra. Raquel Assed Bezerra Segato

Departamento de Clinica Infantil

desta Faculdade

$\sqrt[J d c]{ }$ 



\title{
ANEXO B
}

\section{acturg}

\section{TERMO DE ACEITAÇÃO DE APOIO FINANCEIRO APROPOSTA DE NATUREZA CIENTIFICA, TECNOLÓGICAEJOU DE INOVAÇÄO}

\author{
Processo: 444604/2014-6 \\ Titulo do Projeto: ESTUDO MICROSCOPICO E MOLECULAR DO PAPEL DOS OSTEOCITOS NAFORMAÇÃO E PROGRESSÃO \\ DE LESOES PERIAPICAIS \\ Instituiçăło de Vinculo; Universidade de Såo Paulo/USP.SP \\ CNPJ: 63025530000104 \\ Instituiçato de Execuçăo: Universidade de Sâo Paulo \\ CNPJ: 63025530000104 \\ Chamada: MCTVCNPQ/Universal 14/2014 - Faixa B - até R\$ 60.000,00 \\ Eu, Raquel Assed Bezerra Segato, 293.250.318-92, declaro conhecer, concordar e atender integralmente ats exightncias N $\mathrm{N}^{\circ} \mathrm{CPF}$ (ou \\ PASSAPORTE, se estrangeiro) da Chamada acima especificada e ês Condiçסes Gerais para Apoio Financeiro que regem a \\ concessâo dos recursos especificados abaixo:
}

\section{AUXILIO FINANCEIRO}

Custeio: R\$ $38.000,00$

Valor Global: R\$ $38.000,00$

BOLSADE LONGADURAÇÃO

Modalidade: Iniciaçbo Cientfica - IC

Duração: 36 Meses

Quantidade: 1

Tenho ciência:

a) de que o prazo para utlizaçấo dos recursos financeiros começa a vigorar a partí da data da assinatura deste Termo de Aceitaçăo, pelo periodo constante na Chamada correspondente; $e$

b) das disposiçōes legais e procedimentos para a adequada utilizaçăo de recursos financeiros e a correta prestaçâo de contas (Manual de Utizaçẫo de Recursos Financeiros e Prestaçâa de Contas).

\section{DACONCESSĀO:}

1.1. Ao aceltar o apoio financeiro, O BENEFICLLRIO declara formalmente:

a) dedicar-se als atividades pertinentes à proposta aprovada;

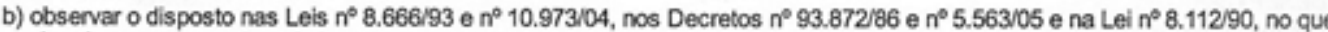
couber, bem como os demais instrumentos legais pertinentes:

c) conhecer o Protocolo de Cooperaçấo Tecnica firmado entre a instituiçăo de execuçâo do projeto/plano de trabalho e o CNPq. publicado no Diário Oficial da Uniăo:

d) conhecer e cumprir as exigências da Chamada à qual a proposta estâ relacionada, como tambèm as normas do CNPq. ora em validade, relativas â modalidade de apolo financeiro aprovado, ciente que a eventual mudança dessas normas năo afeta, altera ou incide sobre o presente documento, exceto quando proposta pelo CNPq e formalmente aceita pelo BENEFICLARIO;

e) possuir anuência formal da instituiçâo de execuçăo do projeto/plano de trabalho, seja sob a forma de vinculo empregaticio ou funcional ou, na ausência deste, sob a forma de declaraçáo de autoridade institucional competente, segundo modelo disponivel na página do $\mathrm{CNPq}$ na Internet: 